\title{
19. GEOCHEMISTRY AND DIAGENESIS OF INTERSTITIAL FLUIDS AND ASSOCIATED CALCAREOUS OOZES, DEEP SEA DRILLING PROJECT, LEG 27, SITE 262, TIMOR TROUGH
}

\author{
Peter J. Cook,' Bureau of Mineral Resources, Canberra, Australia
}

\begin{abstract}
Detailed geochemical work was undertaken on pore water and sediment samples from a drill hole (Site 262) situated on the axis of the Timor Trough. The sediments comprise calcareous ooze with variable quantities of clay minerals. High-magnesian calcite is absent, though aragonite is present throughout the sequence. Dolomite rhombs are common, particularly in the lower half of the section, where they are believed to have formed diagenetically by the action of saline pore fluids on the calcareous ooze. Factors influencing the chemistry of the pore waters include:

1) The increasing carbonate content of the sediments with increasing depth has a relatively minor effect on the chemistry of the pore water.

2) The presence of large amounts of plant material in the sediments and the associated bacterial fermentation and sulfate reduction produce a solution rich in $\mathrm{HCO}_{3}$ (and an abnormally high alkalinity) and a depletion of $\mathrm{SO}_{4}$. There is also a decrease in the $\mathrm{Ca}^{++}$concentration, but the reasons for this are less apparent.

3) The influx of highly saline water in the lower half of the section is believed to emanate from evaporite deposits.
\end{abstract}

\section{INTRODUCTION}

Continuous coring of pelagic calcareous sediments at Site 262 in the Timor Trough (Figure 1), at a water depth of 2315 meters, provided abundant core material for geochemical work, including onboard extraction of interstitial water. Material, $6 \mathrm{~cm}$ long, was taken from each core, at a vertical sampling interval of approximately 10 meters, compared to the normal sampling interval of approximately 50 meters. Because comparatively large amounts of sediment and water were available, it was also possible to undertake a wide range of analyses on the 45 samples obtained.

The drill hole intercepted a total of 442 meters of gray calcareous sediments. The sequence was composed of 414 meters of Quaternary and Pliocene planktonic ooze overlying 13 meters of Pliocene shallow marine foraminiferal dolomitic mud and 15 meters of Pliocene very shallow marine dolomitic shell calcarenite.

Thus, the sequence becomes progressively of shallower water origin with increasing depth down the hole. It is also evident that for the past 4-5 m.y. a comparatively rapid rate of deep-sea sedimentation (about $10 \mathrm{~cm} / 1000$ y) has prevailed in the Timor Trough.

\section{ANALYTICAL PROCEDURES}

After onboard extraction, using a modified hydraulic press, the interstitial water was stored in sealed plastic

'Published with the permission of the Director, Bureau of Mineral Resources, Geology and Geophysics, Canberra, Australia. tubes of about $10-20 \mathrm{ml}$ in volume. A small quantity of water was used for onboard analysis, including the determination of $p \mathrm{H}$ by the flow-through and punch-in methods, alkalinity by potentiometric titration, and salinity by the refractive-index method using a Goldberg optical refractometer. All the onboard analyses and the methods used are standard for each leg of the Deep Sea Drilling Project.

The squeezed sediments were heat-sealed in plastic bags, and dried and ground to approximately 100 mesh before analysis. Chemical analyses on the water and sediment were subsequently undertaken at the Australian Mineral Development Laboratories, Adelaide; mineralogical analyses were carried out at the Bureau of Mineral Resources, Canberra.

\section{Onshore Water Analyses}

Immediately upon opening the vials, the samples were acidified with a known volume of $10 \%$ hydrochloric acid. Analyses were then undertaken as follows:

$\mathrm{Ca}, \mathrm{Mg}, \mathrm{Sr}$, and $\mathrm{Ba}$ were determined by atomic absorption spectrometry using a nitrous oxide flame, a dilution ranging from 10 -fold to 50 -fold, and, where appropriate, an acid solution of $\mathrm{KCl}$ to suppress ionization. $\mathrm{Fe}, \mathrm{Mn}$, and $\mathrm{Zn}$ were determined directly by air-acetylene flame atomic absorption spectrometry using $\times 20$ and $\times 30$ scale expansions, and reading on a chart recorder; background corrections were made using a hydrogen lamp. Cu was determined by air-acetylene flame atomic absorption spectrometry after extraction, using methyl isobutyl ketone as the solvent and ammonium pyrrolidine thiocarbamate as the chelating agent (St. John, 1970). $\mathrm{P}_{2} \mathrm{O}_{5}$ was determined colorimetrically after neutralizing with $\mathrm{NaOH}$ solution. 


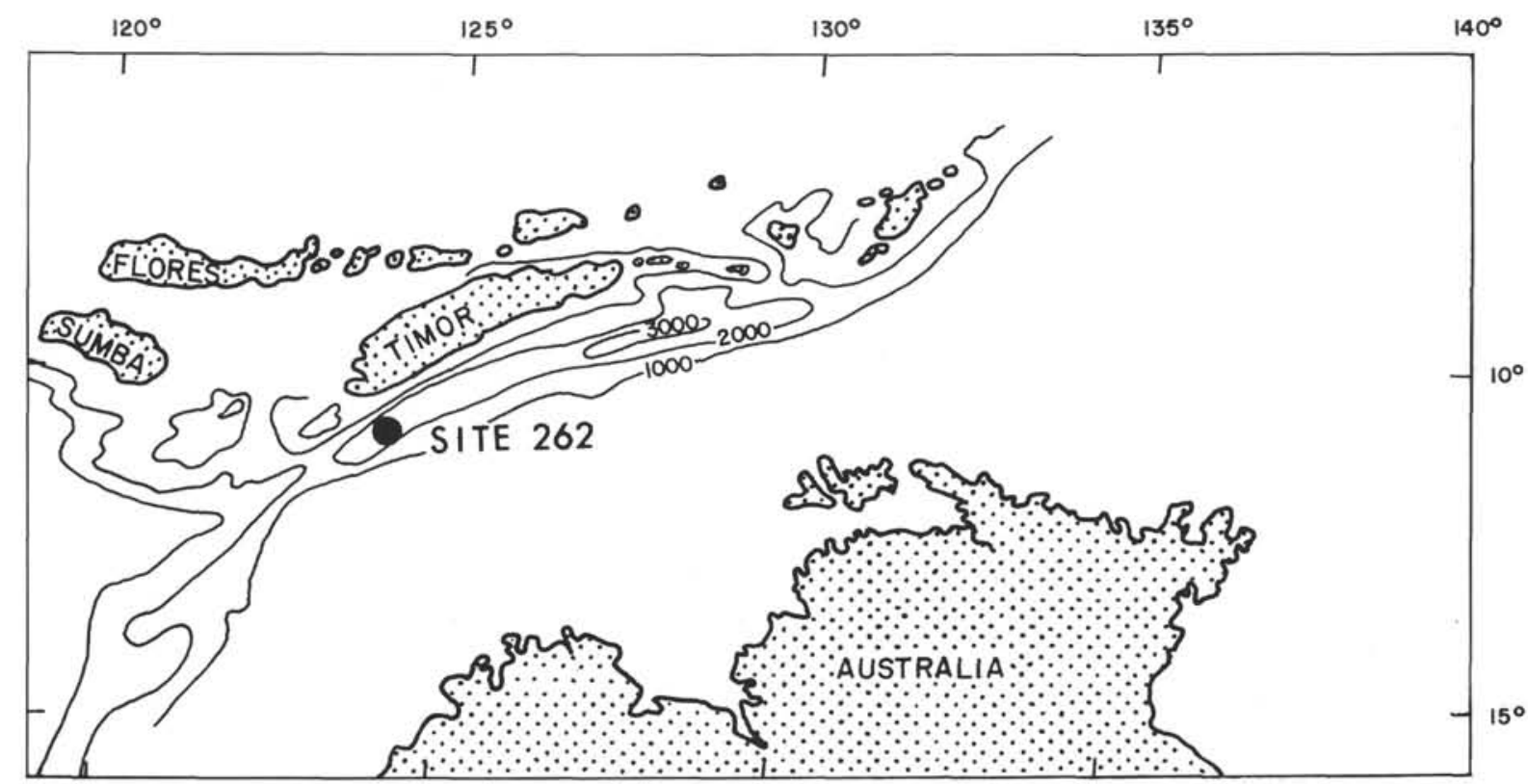

Figure 1. Location of Site 262.

Absorbance was read at $880 \mathrm{~nm}$ in 2-cm cells against standards prepared in a similar matrix of $\mathrm{NaCl}$. This method is fully described by Murphy and Riley (1962). Chloride was determined by titration against silver sulfate using an electrometric endpoint. Sulfate could not be determined by the classical precipitation method because of the small amount of material available so it was obtained by determining the amount of $\mathrm{Ba}$ (by atomic absorption spectrometry) precipitated from solution as $\mathrm{BaSO}_{4}$.

\section{Onshore Sediment Analyses}

Mineralogical analyses were undertaken on a conventional Phillips X-ray-diffraction unit at standard settings. Preferred orientation effects were minimized by the use of a spinner. Calcined fluorite was used as an internal standard. Peak areas were determined using an electrically triggered planimeter. Peak positions were also measured, and the Goldsmith and Graf (1958) relation was used for the determination of carbonate mineralogy.

Various techniques were used for the chemical analyses. $\mathrm{P}_{2} \mathrm{O}_{5}$ was determined spectrophotometrically using the molybdenum blue method. $\mathrm{CO}_{2}$ was determined gravimetrically. All other elements were determined by atomic absorption spectroscopy on total solutions of the samples using mixed acids and HF.

To check the mineralogical significance of geochemical results, a number of samples were impregnated and thin sections cut.

\section{RESULTS}

The results of pore water and sediment analysis of the 45 samples from Site 262 are given in Table 1. Tests of precision were undertaken on both pore water and sediment samples where sufficient material was available. In general, standards of reproducibility for pore water analyses are acceptable, including those for $\mathrm{Mg}( \pm 2.4 \%), \mathrm{Ca}( \pm 2.2 \%), \mathrm{K}( \pm 1.7 \%), \mathrm{Sr}( \pm 2.6 \%), \mathrm{Li}$ $( \pm 3.5 \%), \mathrm{Cl}^{-}( \pm 0.5 \%)$, and $\mathrm{SO}^{--}( \pm 1.0 \%)$. Less satisfactory levels of precision were obtained for $\mathrm{P}_{2} \mathrm{O}_{5}$ $( \pm 34.0 \%), \mathrm{Fe}( \pm 23.2 \%), \mathrm{Mn}( \pm 19.1 \%)$, and $\mathrm{Zn}$ $( \pm 26.7 \%)$.

Precision levels are generally good for the sediment analyses, including those for $\mathrm{Ca}( \pm 0.6 \%), \mathrm{Mg}( \pm 1.9 \%)$, $\mathrm{Sr}( \pm 1.3 \%), \mathrm{Li}(0 \%), \mathrm{Fe}( \pm 1.5 \%), \mathrm{CO}_{2}( \pm 1.7 \%), \mathrm{Cu}$ $( \pm 2.8 \%), \mathrm{Mn}( \pm 1.9 \%)$, and $\mathrm{P}_{2} \mathrm{O}_{5}( \pm 3.8 \%)$. Acceptable levels were obtained for $\mathrm{K}( \pm 7.0 \%), \mathrm{Ba}( \pm 8.7 \%), \mathrm{Zn}$ $( \pm 6.6 \%)$, and $\mathrm{Cr}( \pm 8.8 \%)$. Poor levels of precision were obtained for $\mathrm{Pb}( \pm 30 \%)$, Co $( \pm 11.9 \%)$, and $\mathrm{Ni}$ $( \pm 25.9 \%)$.

The degree of accuracy is more difficult to establish, and is rather less important to a relative study of this type, than the precision. Comparison of the Timor Sea surface-water analyses with those of standard seawater suggests that a reasonable level of accuracy was obtained.

Mean compositions for the upper and lower halves of the section at Site 262 are given in Tables 2 and 3. In addition, the vertical variation in major and trace element compositions of the pore water and the sediment is shown in Figures 2 and 3.

\section{Pore Waters}

\section{DISCUSSION}

Mean pore-water compositions for Site 262 are given in Table 2. Many of the values do not appear to differ significantly from values obtained from Leg 8 (Presley and Kaplan, 1971; Manheim and Sayles, 1971). However, there are some notable differences including salinity, alkalinity, chlorinity, $\mathrm{Ba}$, and $\mathrm{Fe}$ which are considerably greater, and $\mathrm{SO}_{4}^{--}, \mathrm{Ca}$, and $\mathrm{Mn}$ which are significantly less at Site 262 than in Pacific sediments obtained on Leg 8 . It seems probable that the pore waters at Site 262 show marked enrichment in total dis- 
TABLE 1

Composition of Interstitial Waters and Associated Sediments from Site 262, Timor Trough

\begin{tabular}{|c|c|c|c|c|c|c|c|c|c|c|c|c|c|c|c|c|c|c|c|c|c|c|c|}
\hline & \multicolumn{23}{|c|}{ Core No. } \\
\hline & 1 & 2 & 3 & 4 & 5 & 6 & 7 & 8 & 9 & 10 & 11 & 12 & 13 & 14 & 15 & 16 & 17 & 18 & 19 & 20 & 21 & 22 & 23 \\
\hline Section & 4 & 4 & 5 & 3 & 4 & 6 & 1 & 6 & 5 & 1 & 6 & 6 & 1 & 1 & 6 & 6 & 6 & 4 & 5 & 3 & 6 & 5 & 6 \\
\hline Depth $(m)$ & 3.50 & 9.50 & 18.96 & 27.00 & 38.00 & 50.50 & 52.50 & 69.50 & 77.50 & 81.00 & 98.00 & 107.50 & 109.50 & 120.44 & 136.00 & 145.50 & 156.44 & 161.50 & 173.94 & 180.44 & 193.00 & 201.00 & 212.00 \\
\hline Stratigraphic Unit & 1 & 1 & 1 & 1 & 1 & 1 & 1 & 1 & 1 & 1 & 1 & 1 & 1 & 1 & 1 & 1 & 1 & 1 & 1 & 1 & 1 & 2 & 2 \\
\hline \multicolumn{24}{|l|}{ Pore Water } \\
\hline$p \mathrm{H}(\mathrm{tt})$ & 7.12 & 7.55 & 7,62 & 7.72 & 7.72 & 7.67 & 7.80 & 7.92 & 7.63 & 7.86 & 7.80 & 7.86 & 7.85 & 7.77 & 7.77 & 7.83 & 7.71 & 7.64 & 7.84 & 7.81 & 7.66 & 7.72 & 7.47 \\
\hline$p \mathrm{H}(\mathrm{pi})$ & 7.12 & 7.50 & 7.40 & 7.48 & 7.62 & 7.40 & 7.55 & 7.48 & 7.52 & 7.65 & 7.90 & 7.64 & 7.64 & 7.53 & 7.54 & 7.61 & 7.46 & 7.47 & 7.52 & - & - & - & - \\
\hline Salinity $(\% \circ)$ & 33.6 & 36.3 & 37.4 & 37.4 & 37.4 & 38.0 & 37.4 & 36.6 & 36.3 & 36.3 & 35.5 & 35.2 & 35.2 & 34.9 & 35.2 & 35.8 & 36.3 & 36.3 & 36.0 & 37.1 & 36.8 & 36.8 & 36.8 \\
\hline Alkalinity (meq/l) & 22.48 & 73.22 & 87.39 & 90.32 & 87.19 & 92.86 & 82.21 & 76.93 & 65.59 & 63.64 & 53.37 & 50.64 & 45.36 & 36.27 & 47.07 & 50.44 & 52.59 & 48,19 & 49.95 & 51.22 & 46.92 & 39.59 & 28.05 \\
\hline $\mathrm{SO}_{4}(\mathrm{ppm})$ & 500 & 50 & 50 & 50 & 100 & 50 & so & 100 & 50 & $1 \mathrm{~s}^{\mathrm{a}}$ & so & 50 & 100 & 200 & 100 & 50 & $1 \mathrm{~S}^{\mathrm{a}}$ & so & 50 & 50 & 50 & 50 & 100 \\
\hline $\mathrm{Cl}(\% \circ)$ & 19.4 & 19.6 & 19.6 & 19.9 & 19.9 & 19.9 & 19.9 & 19.8 & 20.0 & IS $^{\mathrm{a}}$ & 20.0 & 20.0 & 20.0 & 19.9 & 20.2 & 20.3 & 20.5 & 20.8 & 21.0 & 21.1 & 21.6 & 21.7 & 21.9 \\
\hline $\mathrm{P}_{2} \mathrm{O}_{5}(\mathrm{ppm})$ & 0.41 & 16.0 & 22.5 & 15.1 & 15.5 & 25.6 & 23.3 & 23.3 & 16.0 & 14.2 & 12.8 & 11.0 & 10.6 & 10.8 & 13.5 & 13.8 & 10.4 & 11.5 & 8.9 & 8.4 & 7.95 & 5.75 & 2.85 \\
\hline $\mathrm{Mg}(\mathrm{ppm})$ & 1240 & 1470 & 1530 & 1500 & 1530 & 1560 & 1500 & 1340 & 1240 & 1270 & 1160 & 1130 & 1130 & 1180 & 1180 & 1190 & 1270 & 1270 & 1290 & 1340 & 1240 & 1250 & 1080 \\
\hline $\mathrm{Ca}(\mathrm{ppm})$ & 156 & 40 & 35 & 28 & 32 & 26 & 230 & 35 & 40 & 40 & 40 & 40 & 38 & 62 & 38 & 35 & 38 & 46 & 32 & 28 & 32 & 59 & 62 \\
\hline $\mathrm{K}(\mathrm{ppm})$ & 365 & 560 & 575 & 515 & 585 & 610 & 600 & 590 & 560 & 595 & 525 & 550 & 595 & 565 & 575 & 565 & 575 & 510 & 555 & 565 & 565 & 510 & 525 \\
\hline $\mathrm{Sr}(\mathrm{ppm})$ & 8.2 & 3.6 & 3.1 & 2.6 & 2.6 & 2.0 & 1.8 & 2.8 & 3.6 & 3.6 & 4.1 & 4.2 & 3.9 & 4.4 & 4.1 & 4.1 & 4.2 & 4.8 & 3.9 & 3.9 & 4.6 & 7.4 & 8.9 \\
\hline $\mathrm{Ba}(\mathrm{ppm})$ & 0.5 & 13.8 & 9.2 & 7.4 & 7.0 & 6.2 & 4.4 & 6.8 & 9.4 & 9.2 & 11.0 & 10.6 & 10.0 & 6.2 & 12.0 & 14.6 & 15.4 & 16.6 & 15.0 & 15.0 & 17.0 & 21.2 & 23.2 \\
\hline $\mathrm{Li}(\mathrm{ppm})$ & 0.14 & 0.13 & 0.13 & 0.15 & 0.15 & 0.15 & 0.15 & 0.17 & 0.19 & 0.20 & 0.22 & 0.22 & 0.22 & 0.21 & 0.21 & 0.25 & 0.23 & 0.21 & 0.25 & 0.26 & 0.26 & 0.27 & 0.34 \\
\hline $\mathrm{Cu}(\mathrm{ppm})$ & 0.01 & 0.01 & 0.01 & 0.05 & 0.01 & 0.03 & 0.01 & 0.03 & 0.13 & 0.07 & 0.05 & 0.04 & 0.03 & 0.09 & 0.04 & 0.07 & 0.04 & 0.04 & 0.04 & 0.04 & 0.02 & 0.06 & 0.03 \\
\hline $\mathrm{Fe}(\mathrm{ppm})$ & 0.06 & 0.08 & IS & 0.24 & 0.24 & 0.22 & 0.21 & IS & 0.26 & 0.24 & 0.17 & 0.19 & 0.19 & 0.10 & 0.19 & 0.27 & 0.12 & 0.20 & 0.14 & 0.19 & 0.17 & 0.57 & 0.19 \\
\hline $\mathrm{Mn}(\mathrm{ppm})$ & 0.60 & 0.009 & 0.09 & 0.05 & 0.05 & 0.06 & 0.05 & 0.05 & 0.06 & 0.07 & 0.06 & 0.05 & 0.07 & 0.09 & 0.08 & 0.07 & 0.08 & 0.06 & 0.05 & 0.05 & 0.06 & 0.24 & 0.09 \\
\hline $\mathrm{Zn}(\mathrm{ppm})$ & 0.42 & 0.68 & 0.34 & 0.31 & 0.22 & 0.23 & 0.21 & 0.28 & 0.28 & 0.51 & 0.24 & 0.20 & 0.15 & 0.27 & 0.18 & 0.23 & 0.20 & 0.17 & 0.19 & 0.18 & 0.15 & 2.68 & 0.22 \\
\hline \multicolumn{24}{|l|}{ Sediment } \\
\hline $\mathrm{Fe}(\%)$ & 2.1 & 2.5 & 2.5 & 2.8 & 2.8 & 2.8 & 2.7 & 3.0 & 3.0 & 3.0 & 3.1 & 3.0 & 2.9 & 3.2 & 2.9 & 3.2 & 2.9 & 3.0 & 2.8 & 3.0 & 2.9 & 3.0 & 3.1 \\
\hline $\mathrm{Al}_{2} \mathrm{O}_{3}(\%)$ & 7.9 & 8.9 & 8.6 & 9.5 & 9.4 & 9.0 & 8.7 & 9.5 & 9.6 & 10.3 & 9.7 & 10.6 & 11.1 & 11.2 & 10.6 & 11.1 & 9.7 & 10.2 & 10.6 & 10.7 & 9.5 & 10.3 & 9.6 \\
\hline $\mathrm{CO}_{2}(\%)$ & 21.2 & 15.1 & 13.8 & 12.5 & 13.9 & 15.4 & 15.3 & 14.3 & 13.3 & 12.1 & 12.4 & 11.3 & 12.0 & 12.3 & 14.0 & 11.9 & 13.2 & 13.2 & 13.3 & 14.9 & 13.4 & 13.6 & 14.4 \\
\hline $\mathrm{Ca}(\%)$ & 18.0 & 14.3 & 13.0 & 11.9 & 12.8 & 14.5 & 14.0 & 13.3 & 12.5 & 10.8 & 10.6 & 10.1 & 11.0 & 11.1 & 12.9 & 10.7 & 12.3 & 11.8 & 12.2 & 13.4 & 13.1 & 12.1 & 13.3 \\
\hline $\mathrm{Mg}(\%)$ & 1.5 & 1.25 & 1.15 & 1.2 & 1.15 & 1.2 & 1.15 & 1.2 & 1.25 & 1.15 & 1.25 & 1.3 & 1.2 & 1.2 & 1.15 & 1.25 & 1.15 & 1.3 & 1.2 & 1.3 & 1.2 & 1.35 & 1.2 \\
\hline K (\%) & 0.84 & 1.2 & 1.2 & 1.25 & 1.24 & 1.1 & 1.2 & 1.35 & 1.4 & 1.4 & 1.45 & 1.55 & 1.45 & 1.5 & 1.45 & 1.15 & 1.35 & 1.45 & 1.6 & 1.45 & 1.45 & 1.55 & 1.5 \\
\hline $\operatorname{Sr}(\mathrm{ppm})$ & 1000 & 10800 & 700 & 600 & 700 & 850 & 850 & 800 & 750 & 600 & 550 & 500 & 550 & 550 & 650 & 450 & 650 & 650 & 600 & 650 & 700 & 650 & 650 \\
\hline $\mathrm{Ba}(\mathrm{ppm})$ & 350 & 450 & 460 & 420 & 410 & 410 & 450 & 400 & 410 & 400 & 420 & 380 & 420 & 410 & 450 & 400 & 450 & 460 & 440 & 470 & 450 & 470 & 440 \\
\hline Li (ppm) & 20 & 30 & 30 & 30 & 30 & 30 & 30 & 30 & 30 & 30 & 30 & 40 & 30 & 40 & 30 & 40 & 30 & 40 & 30 & 40 & 30 & 40 & 40 \\
\hline $\mathrm{Cu}(\mathrm{ppm})$ & 40 & 45 & 45 & 45 & 45 & 45 & 40 & 45 & 45 & 45 & 50 & 50 & 45 & 45 & 45 & 45 & 45 & 45 & 45 & 40 & 45 & 45 & 45 \\
\hline $\mathrm{Pb}(\mathrm{ppm})$ & 15 & 13 & 10 & 8 & 5 & 8 & 13 & 8 & 10 & 15 & 20 & 8 & 5 & 18 & 15 & 15 & 10 & I & 10 & 15 & 8 & 15 & 10 \\
\hline $\mathrm{Zn}(\mathrm{ppm})$ & 75 & 65 & 80 & 85 & 85 & 85 & 90 & 90 & 90 & 90 & 85 & 90 & 90 & 95 & 90 & 90 & 90 & 95 & 95 & 95 & 95 & 100 & 95 \\
\hline Co (ppm) & 5 & 13 & 3 & 8 & 5 & 10 & 8 & 8 & 8 & 10 & 8 & 10 & 15 & 10 & 10 & 10 & 13 & 4 & 8 & 4 & 10 & 8 & 8 \\
\hline $\mathrm{Ni}(\mathrm{ppm})$ & 30 & 40 & 40 & 40 & 35 & 35 & 35 & 40 & 40 & 40 & 40 & 45 & 45 & 45 & 40 & 40 & 35 & 30 & 35 & 40 & 35 & 40 & 45 \\
\hline $\mathrm{Mn}(\mathrm{ppm})$ & 410 & 900 & 700 & 900 & 800 & 700 & 650 & 650 & 900 & 1000 & 1100 & 1100 & 800 & 1200 & 1200 & 1100 & 700 & 900 & 900 & 900 & 750 & 750 & 750 \\
\hline $\operatorname{Cr}(\mathrm{ppm})$ & 65 & 75 & 85 & 70 & 105 & 80 & 85 & 75 & 70 & 85 & 90 & 90 & 70 & 65 & 60 & 90 & 70 & 65 & 75 & 90 & 75 & 95 & 85 \\
\hline $\mathrm{P}_{2} \mathrm{O}_{5}(\mathrm{ppm})$ & 1168 & 1146 & 1237 & 1260 & 1260 & 1260 & 1283 & 1260 & 1260 & 1283 & 1283 & 1260 & 1260 & 1260 & 1260 & 1260 & 1168 & 1191 & 1260 & 1260 & 1146 & 1123 & 1077 \\
\hline \multicolumn{24}{|c|}{ Carbonate Components } \\
\hline Dolomite $(\%)$ & 16.6 & - & - & - & - & - & 4.5 & - & - & - & 5.6 & 2.9 & - & - & 3.3 & - & - & 2.7 & 1.8 & 2.4 & 1.8 & 3.1 & 1.8 \\
\hline Calcite $(\%)$ & 78.7 & 93.8 & 92.1 & 94.8 & 93.3 & 93.2 & 88.6 & 91.6 & 90.9 & 93.8 & 89.8 & 91.2 & 95.9 & 95.7 & 94.8 & 98.7 & 97.3 & 92.0 & 95.2 & 95.8 & 95.1 & 93.9 & 95.1 \\
\hline Aragonite (\%) & 4.7 & 6.2 & 7.9 & 5.2 & 6.7 & 6.8 & 6.8 & 8.4 & 9.1 & 6.2 & 4.6 & 5.9 & 4.1 & 4.3 & 2.0 & 1.3 & 2.7 & 5.3 & 3.0 & 1.8 & 3.1 & 3.1 & 3.0 \\
\hline
\end{tabular}




\begin{tabular}{|c|c|c|c|c|c|c|c|c|c|c|c|c|c|c|c|c|c|c|c|c|c|c|}
\hline & \multicolumn{22}{|c|}{ Core No. } \\
\hline & 24 & 25 & 26 & 27 & 28 & 29 & 30 & 31 & 32 & 33 & 34 & 35 & 36 & 37 & 38 & 39 & 40 & 41 & 42 & 43 & 44 & 45 \\
\hline Section & 6 & 5 & 5 & 4 & 3 & 5 & 5 & 6 & 6 & 6 & 4 & 6 & 6 & 6 & 5 & 5 & 5 & 6 & 5 & 2 & 3 & 6 \\
\hline Depth (m) & 221.5 & 229.5 & 239.0 & 247.0 & 255.0 & 267.5 & 277.0 & 288.0 & 297.5 & 307.0 & 313.5 & 326.0 & 335.5 & 345.0 & 353.0 & 362.5 & 372.0 & 383.0 & 391.0 & 396.0 & 407.0 & 421.0 \\
\hline Stratigraphic Unit & 2 & 2 & 2 & 2 & 2 & 2 & 2 & 2 & 2 & 2 & 2 & 2 & 2 & 3 & 3 & 3 & 3 & 3 & 3 & 3 & 3 & 4 \\
\hline \multicolumn{23}{|l|}{ Pore Water } \\
\hline$p \mathrm{H}(\mathrm{ft})$ & 7.47 & 7.61 & 8.04 & 8.17 & 7.58 & 7.65 & 7.45 & 7.50 & 7.67 & 7.44 & 7.50 & 7.75 & 7.70 & 7.83 & 7.71 & 7.38 & 7.73 & 7.98 & 8.09 & 8.01 & 7.68 & 7.41 \\
\hline$p \mathrm{H}(\mathrm{pi})$ & - & - & - & - & - & - & - & - & - & - & - & - & - & - & - & - & - & - & - & - & - & - \\
\hline Salinity $(\% \circ)$ & 33.6 & 36.8 & 37.7 & 38.2 & 38.5 & 38.5 & 38.5 & 39.9 & 39.6 & 41.5 & 41.5 & 42.6 & 43.7 & 43.7 & 44.6 & 47.3 & 45.6 & 49.8 & 48.1 & 48.1 & 51.4 & 53.1 \\
\hline Alkalinity (meq/) & 19.45 & 24.14 & 15.73 & 11.14 & 14.47 & 5.77 & 6.74 & 5.96 & 4.20 & 4.69 & 4.30 & 2.93 & 3.03 & 1.96 & 2.35 & 2.93 & 1.96 & 1.37 & 0.88 & 0.98 & 1.37 & 1.96 \\
\hline $\mathrm{SO}_{4}(\mathrm{ppm})$ & 100 & so & 50 & 50 & 50 & 50 & 240 & 50 & 50 & 140 & 50 & 50 & 240 & so & 100 & 50 & $1 \mathrm{~S}^{\mathrm{a}}$ & 470 & 750 & 930 & 820 & $I^{\mathrm{a}}$ \\
\hline $\mathrm{Cl}(\% \mathrm{oo})$ & 22.2 & 22.4 & 23.2 & 23.6 & 24.1 & 24.2 & 24.1 & 25.3 & 24.1 & 26.1 & 26.4 & 27.1 & 27.3 & 28.2 & 28.2 & 32.3 & IS $^{\mathrm{a}}$ & 31.7 & 30.2 & 30.0 & 32.2 & 33.1 \\
\hline $\mathrm{P}_{2} \mathrm{O}_{5}(\mathrm{ppm})$ & 1.16 & 2.63 & 2.38 & 2.02 & 1.55 & 0.85 & 2.48 & 1.59 & 0.63 & 0.71 & 0.51 & 0.62 & 1.01 & 0.60 & 0.55 & 0.63 & 0.94 & 0.71 & 0.70 & 0.67 & 0.58 & 1.27 \\
\hline $\mathrm{Mg}(\mathrm{ppm})$ & 995 & 1050 & 1020 & 920 & 955 & 830 & 860 & 845 & 830 & 815 & 860 & 800 & 880 & 800 & 920 & 890 & 990 & 965 & 1020 & 965 & 1020 & 1060 \\
\hline $\mathrm{Ca}(\mathrm{ppm})$ & 102 & 115 & 56 & 42 & 132 & 155 & 241 & 245 & 259 & 285 & 306 & 303 & 355 & 353 & 423 & 538 & 518 & 628 & 658 & 612 & 810 & 896 \\
\hline $\mathrm{K}(\mathrm{ppm})$ & 535 & 485 & 605 & 750 & 570 & 540 & 460 & 485 & 485 & 505 & 480 & 485 & 460 & 435 & 430 & 405 & 415 & 430 & 425 & 415 & 415 & 395 \\
\hline Sr (ppm) & 11.4 & 12.2 & 9.2 & 7.6 & 17.9 & 24.0 & 27,9 & 37.5 & 37.5 & 47.0 & 54.5 & 68.0 & 82.5 & 94.0 & 108 & 117 & 119 & 146 & 140 & 129 & 145 & 123 \\
\hline $\mathrm{Ba}(\mathrm{ppm})$ & 24.7 & 23.1 & 23.8 & 18.4 & 36.1 & 26.9 & 7.6 & 27.8 & 14.0 & 19.4 & 10.4 & 10.4 & 8.4 & 8.8 & 4.0 & 3.0 & 0.8 & 0.6 & 0.7 & 0.4 & 0.5 & 0.4 \\
\hline Li (ppm) & 0.39 & 0.35 & 0.33 & 0.38 & 0.40 & 0.36 & 0.33 & 0.33 & 0.26 & 0.28 & 0.27 & 0.28 & 0.25 & 0.22 & 0.24 & 0.26 & 0.27 & 0.32 & 0.33 & 0.32 & 0.43 & 0.50 \\
\hline $\mathrm{Cu}(\mathrm{ppm})$ & 0.04 & 0.03 & 0.03 & 0.08 & 0.05 & 0.05 & Is & 0.09 & 0.22 & 0.12 & 0.05 & is & 0.05 & 0.14 & 0.07 & 0.08 & 0.08 & 0.08 & 0.08 & 0.08 & 0.07 & 0.07 \\
\hline $\mathrm{Fe}(\mathrm{ppm})$ & 0.10 & 0.09 & 0.03 & 0.12 & 0.20 & 0.38 & 0.20 & 0.38 & 0.12 & 0.49 & 0.21 & 0.14 & 0.13 & 0.13 & 0.19 & 0.36 & 0.30 & 0.30 & 0.30 & 0.26 & 0.21 & 0.20 \\
\hline $\mathrm{Mn}(\mathrm{ppm})$ & 0.10 & 0.17 & 0.05 & 0.07 & 0.07 & 0.41 & 0.04 & 0.04 & 0.03 & 0.03 & 0.04 & 0.04 & 0.04 & 0.04 & 0.02 & 0.03 & 0.03 & 0.04 & 0.04 & 0.04 & 0.05 & 0.05 \\
\hline $\mathrm{Zn}(\mathrm{ppm})$ & 0.21 & 0.22 & 0.88 & 0.24 & 0.24 & 0.16 & 0.35 & 0.31 & 0.14 & 0.27 & 0.27 & 0.17 & 0.23 & 0.47 & 0.33 & 0.40 & 0.40 & 0.35 & 0.35 & 0.30 & 0.29 & 0.29 \\
\hline \multicolumn{23}{|l|}{ Sediment } \\
\hline $\mathrm{Fe}(\%)$ & 2.8 & 2.9 & 2.7 & 2.4 & 1.8 & 1.9 & 1.5 & 1.5 & 2.0 & 1.3 & 1.15 & 2.1 & 1.55 & 2.2 & 0.70 & 0.80 & 0.80 & 0.80 & 1.05 & 0.75 & 0.95 & 0.15 \\
\hline $\mathrm{Al}_{2} \mathrm{O}_{3}(\%)$ & 10.2 & 9.6 & 9.3 & 8.6 & 5.7 & 6.4 & 5.3 & 5.1 & 7.2 & 4.9 & 4.3 & 6.9 & 5.4 & 6.7 & 2.1 & 2.3 & 2.7 & 2.1 & 3.6 & 2.1 & 2.7 & 0.1 \\
\hline $\mathrm{CO}_{2}(\%)$ & 15.4 & 15.3 & 17.0 & 21.3 & 26.6 & 25.7 & 29.6 & 29.2 & 23.4 & 30.1 & 31.3 & 24.2 & 27.0 & 24.9 & 38.8 & 35.4 & 35.3 & 37.5 & 31.0 & 37.5 & 35.0 & 42.9 \\
\hline $\mathrm{Ca}(\%)$ & 14.3 & 14.1 & 15.6 & 19.3 & 23.6 & 22.9 & 27.7 & 26.0 & 21.9 & 27.1 & 28.0 & 21.5 & 24.3 & 21.6 & 32.7 & 30.2 & 30.2 & 30.7 & 26.5 & 31.9 & 28.6 & 31.5 \\
\hline $\mathrm{Mg}(\%)$ & 1.2 & 1.05 & 1.25 & 1.05 & 1.0 & 1.05 & 1.1 & 0.95 & 1.4 & 1.05 & 1.3 & 1.5 & 2.1 & 1.35 & 1.25 & 1.5 & 1.4 & 2.2 & 1.4 & 1.8 & 2.2 & 4.8 \\
\hline K (\%) & 1.5 & 1.45 & 1.4 & 1.15 & 0.88 & 0.97 & 0.73 & 0.79 & 1.1 & 0.71 & 0.63 & 1.1 & 0.78 & 1.05 & 0.25 & 0.40 & 0.39 & 0.31 & 0.58 & 0.31 & 0.44 & 0.05 \\
\hline Sr (ppm) & 750 & 700 & 900 & 1050 & 1500 & 1500 & 2200 & 2300 & 1700 & 2200 & 2600 & 1400 & 1800 & 2100 & 1500 & 1800 & 1700 & 1400 & 2000 & 1600 & 1300 & 600 \\
\hline $\mathrm{Ba}(\mathrm{ppm})$ & 420 & 460 & 480 & 450 & 440 & 330 & 310 & 290 & 260 & 210 & 180 & 160 & 150 & 150 & 90 & 50 & 100 & 70 & 100 & 70 & 90 & 20 \\
\hline $\mathrm{Li}(\mathrm{ppm})$ & 40 & 30 & 30 & 30 & 20 & 30 & 20 & 20 & 30 & 20 & 20 & 30 & 20 & 20 & 10 & 10 & 10 & 10 & 20 & 10 & 10 & 1 \\
\hline $\mathrm{Cu}(\mathrm{ppm})$ & 40 & 45 & 45 & 90 & 30 & 30 & 30 & 25 & 25 & 25 & 25 & 25 & 20 & 20 & 10 & 10 & 10 & 10 & 10 & 4 & 8 & 3 \\
\hline $\mathrm{Pb}(\mathrm{ppm})$ & 20 & 25 & 1 & 1 & 15 & 1 & 5 & 4 & 5 & 2 & 8 & 3 & 10 & 8 & 15 & 8 & 10 & 8 & 10 & 1 & 2 & 2 \\
\hline $\mathrm{Zn}(\mathrm{ppm})$ & 100 & 90 & 95 & 90 & 65 & 75 & 65 & 65 & 75 & 55 & 55 & 70 & 55 & 60 & 30 & 30 & 35 & 3 & 35 & 25 & 3 & 13 \\
\hline Co $(\mathrm{ppm})$ & 1 & 2 & 8 & 4 & 1 & 8 & 1 & 3 & 4 & 1 & 1 & 1 & 1 & 1 & 1 & 1 & 1 & 1 & 1 & 1 & 1 & 1 \\
\hline $\mathrm{Ni}(\mathrm{ppm})$ & 45 & 40 & 40 & 35 & 40 & 40 & 30 & 35 & 30 & 25 & 35 & 30 & 15 & 20 & 10 & 10 & 13 & 8 & 10 & 10 & 8 & 3 \\
\hline $\mathrm{Mn}(\mathrm{ppm})$ & 550 & 600 & 700 & 700 & 340 & 270 & 190 & 190 & 190 & 150 & 120 & 240 & 110 & 120 & 70 & 70 & 65 & 75 & 95 & 70 & 85 & 15 \\
\hline $\mathrm{Cr}(\mathrm{ppm})$ & 90 & 90 & 75 & 30 & 5s & 50 & 50 & 55 & 75 & 45 & 50 & 65 & so & 65 & 35 & 25 & 80 & 50 & 60 & 35 & 50 & 5 \\
\hline $\mathrm{P}_{2} \mathrm{O}_{5}(\mathrm{ppm})$ & 1146 & $\cdot 1054$ & 1375 & 1352 & 1191 & 1489 & 1375 & 1420 & 1489 & 1558 & 1512 & 1260 & 1650 & 1260 & 1398 & 2016 & 1535 & 2635 & 1489 & 2268 & 2635 & 1604 \\
\hline \multicolumn{23}{|c|}{ Carbonate Components } \\
\hline Dolomite (\%) & - & - & 1.2 & - & 5.5 & 4.1 & 6.9 & 5.3 & 10.1 & 6.6 & 11.9 & 19.8 & 31.3 & 8.6 & 11.6 & 20.3 & 15.8 & 36.9 & 14.4 & 22.5 & 23.1 & 63.6 \\
\hline Calcite (\%) & 98.4 & 97.6 & 95.1 & 97.1 & 86.0 & 90.9 & 81.7 & 82.8 & 80.9 & 93.9 & 74.1 & 73.8 & 59.5 & 74.6 & 85.8 & 74.8 & 78.9 & 61.9 & 78.4 & 74.1 & 74.4 & 36.1 \\
\hline Aragonite (\%) & 1.6 & 2.4 & 3.7 & 2.9 & 8.5 & 4.9 & 11.5 & 11.9 & 9.0 & 9.5 & 14.0 & 6.3 & 9.2 & 16.8 & 2.6 & 4.8 & 5.4 & 1.2 & 7.2 & 3.5 & 3.5 & 0.3 \\
\hline
\end{tabular}

Note: $p \mathrm{H}$ salinity, and alkalinity were determined onboard the D/V Glomar Challenger by J. Pine. All other chemical determinations were made by the Australian Mineral Development Laboratories; mineralogical determinations were made by the Bureau of Mineral Resources. 
TABLE 2

Average Composition of Interstitial Waters and Seawater

\begin{tabular}{l|ccccc}
\cline { 2 - 5 } & $\begin{array}{c}\text { Cores } \\
1-23^{\mathrm{a}}\end{array}$ & $\begin{array}{c}\text { Cores } \\
24-45^{\mathrm{b}}\end{array}$ & $\begin{array}{c}\text { Mean Value } \\
\text { for DSDP } \\
\text { Leg } 8\end{array}$ & $\begin{array}{c}\text { Mean Value } \\
\text { for Timor Sea } \\
\text { Surface Water }\end{array}$ & $\begin{array}{c}\text { Standard } \\
\text { Seawater }\end{array}$ \\
\hline$p \mathrm{H}$ & 7.70 & 7.70 & 7.60 & 8.23 & 8 \\
$\mathrm{Salinity}(\% \mathrm{oo})$ & 36.3 & 42.8 & 35.2 & 34.6 & 35.0 \\
Alkalinity (meq/1) & 58.3 & 6.56 & 2.73 & 2.49 & 2 \\
$\mathrm{SO}_{4}(\% / \mathrm{oo})$ & 0.080 & 0.021 & 2.45 & 2.75 & 2.70 \\
$\mathrm{C}^{-}(\% / \mathrm{oo})$ & 21.1 & 26.9 & 19.6 & 19.9 & 19.4 \\
$\mathrm{P}_{2} \mathrm{O}_{5}(\mathrm{ppm})$ & 12.6 & 1.1 & 8.1 & 0.26 & 0.17 \\
$\mathrm{Mg}(\mathrm{ppm})$ & 13.00 & 922 & 1120 & 1310 & 1298 \\
$\mathrm{Ca}(\mathrm{ppm})$ & 53 & 365 & 610 & 433 & 408 \\
$\mathrm{~K}(\mathrm{ppm})$ & 559 & 483 & 390 & 391 & 388 \\
$\mathrm{Sr}(\mathrm{ppm})$ & 4.2 & 28.8 & 25.8 & 7.7 & 8.1 \\
$\mathrm{Ba}(\mathrm{ppm})$ & 11.0 & 12.3 & 0.09 & 0.19 & 0.03 \\
$\mathrm{Li}(\mathrm{ppm})$ & 0.20 & 0.32 & 0.19 & 0.1 & 0.17 \\
$\mathrm{Cu}(\mathrm{ppm})$ & 0.04 & 0.08 & 0.02 & 0.01 & 0.003 \\
$\mathrm{Fe}(\mathrm{ppm})$ & 0.20 & 0.22 & 0.09 & 0.08 & 0.01 \\
$\mathrm{Mn}(\mathrm{ppm})$ & 0.09 & 0.07 & 0.32 & 0.02 & 0.002 \\
$\mathrm{Zn}(\mathrm{ppm})$ & 0.37 & 0.31 & - & 0.07 & 0.01 \\
\hline $\mathrm{Note}$ & & & & & \\
\hline
\end{tabular}

Note: Mean Leg 8 values calculated from Presley and Kaplan (1971) and Manheim and Sayles (1971).

${ }_{b}^{\mathrm{a}}$ Upper part of hole.

Lower part of hole.

TABLE 3

Major and Trace Element Compositions of the Calcareous Oozes in DSDP, Site 262, Timor Trough

\begin{tabular}{|c|c|c|c|c|}
\hline & $\begin{array}{l}\text { Cores } \\
1-23^{a}\end{array}$ & $\begin{array}{l}\text { Cores } \\
24-45^{b}\end{array}$ & $\begin{array}{l}\text { Average Over } \\
\text { Entire Site } \\
262\end{array}$ & $\begin{array}{l}\text { Average Cenozoic } \\
\text { Sediment on Leg } 27 \\
\text { (excluding Site 262) }\end{array}$ \\
\hline $\mathrm{Fe}(\%)$ & 3.0 & 1.5 & 2.2 & 2.32 \\
\hline $\mathrm{A}_{2}{ }_{2} \mathrm{O}_{3}(\%)$ & 9.9 & 5.2 & 7.6 & 7.27 \\
\hline $\mathrm{CO}_{2}(\%)$ & 13.8 & 28.8 & 21.1 & 20.8 \\
\hline $\mathrm{Ca}(\%)$ & 12.6 & 25.0 & 21.0 & 18.7 \\
\hline $\mathrm{Mg}(\%)$ & 1.23 & 1.54 & 1.38 & 1.10 \\
\hline $\mathrm{K}(\%)$ & 1.35 & 0.77 & 1.07 & 1.15 \\
\hline $\mathrm{Sr}(\mathrm{ppm})$ & 1105 & 1572 & 1333 & 1830 \\
\hline $\mathrm{Ba}(\mathrm{ppm})$ & 432 & 222 & 329 & 500 \\
\hline $\mathrm{Li}(\mathrm{ppm})$ & 33 & 20 & - & 30 \\
\hline $\mathrm{Cu}(\mathrm{ppm})$ & 45 & 22 & - & 21 \\
\hline $\mathrm{Pb}(\mathrm{ppm})$ & 11 & 7.5 & 9.3 & 12 \\
\hline $\mathrm{Zn}(\mathrm{ppm})$ & 89 & 54 & 72 & 85 \\
\hline Co (ppm) & 9 & 2 & 6 & 18 \\
\hline $\mathrm{Ni}$ (ppm) & 39 & 24 & 32 & 75 \\
\hline Mn (ppm) & 860 & 228 & 544 & 2600 \\
\hline $\mathrm{Cr}$ (ppm) & 79 & 54 & 67 & 600 \\
\hline $\mathrm{P}_{2} \mathrm{O}_{5}(\mathrm{ppm})$ & 1227 & 1578 & 1403 & 1600 \\
\hline Dolomite (\%) & 2.0 & 14.5 & 8.3 & - \\
\hline Calcite (\%) & 93.2 & 79.1 & 86.2 & - \\
\hline Aragonite (\%) & 4.8 & 4.4 & 5.5 & - \\
\hline
\end{tabular}

${ }^{\mathrm{a}}$ Upper part of hole.

$b_{\text {Lower part of hole. }}$ 

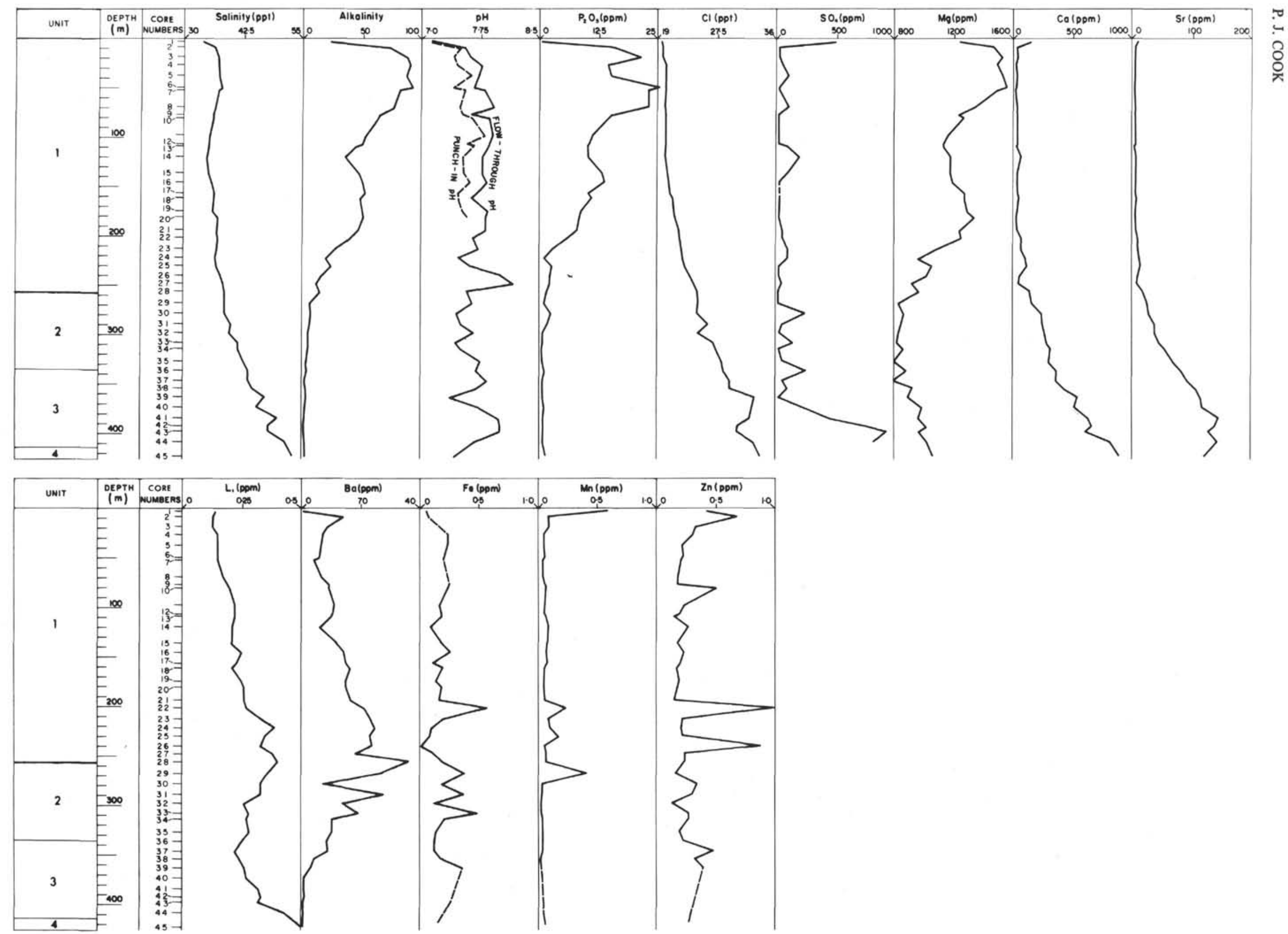

Figure 2. Vertical variation in the chemical composition of pore waters from Site 262. 

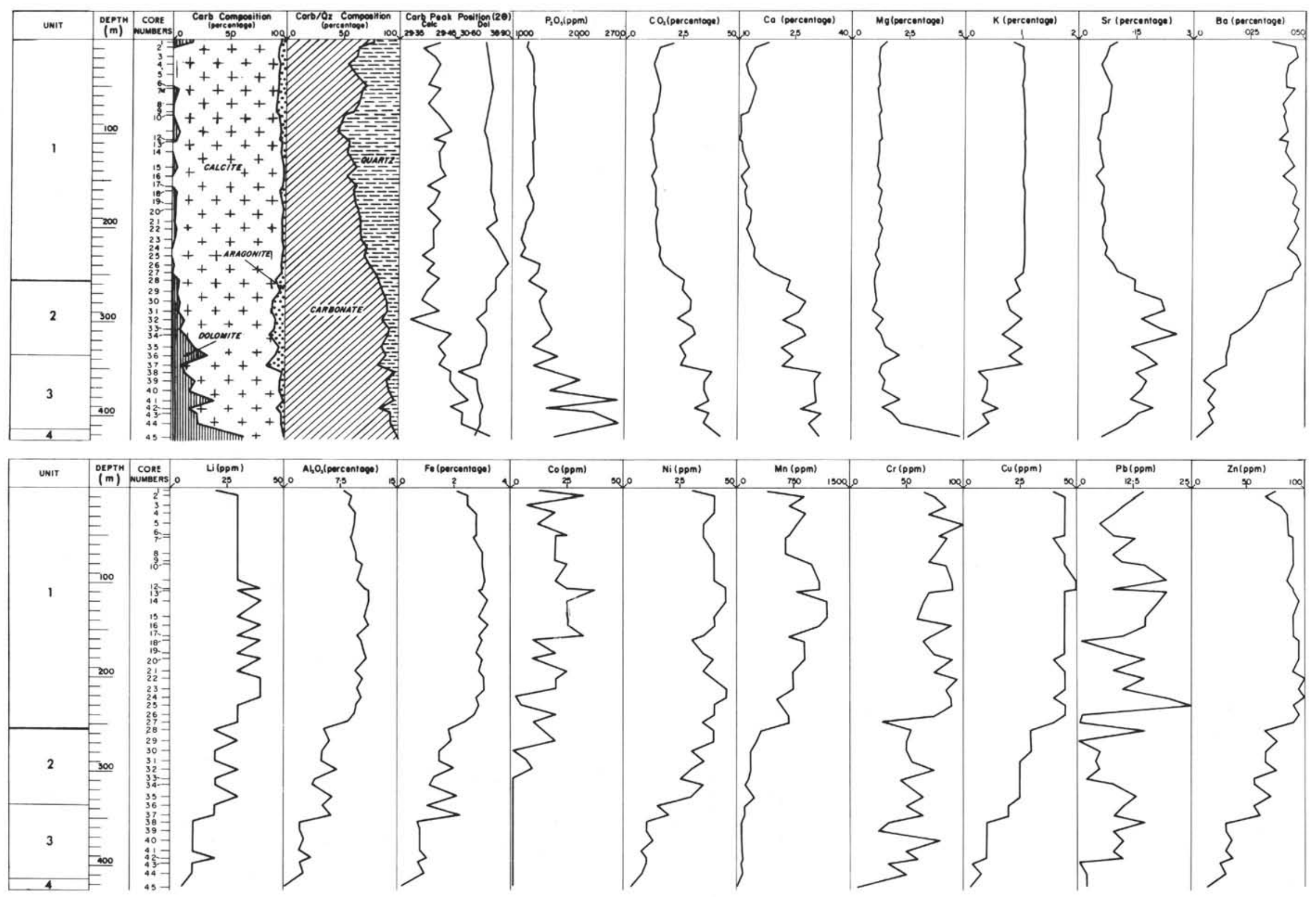

勇

Figure 3. Vertical variation in the chemical and mineralogical composition of Site 262. 
solved salts, $\mathrm{PO}, \mathrm{K}, \mathrm{Ba}, \mathrm{Fe}, \mathrm{Mn}, \mathrm{Zn}$, and $\mathrm{HCO}_{3}$ (as indicated by the alkalinity value) and significant depletion in $\mathrm{SO}_{4}$ and $\mathrm{Ca}$ when compared with Timor Sea surface water.

Equally marked differences between the elemental composition of pore waters in the upper part of the hole and those in the lower part are also apparent from Table 2. It is clear from Figure 2 that these vertical changes are, in general, gradational and that many of them are interrelated, with, for instance, $\mathrm{Sr}$ varying sympathetically with $\mathrm{Ca}$. Some of these interrelations will be discussed in some detail.

Using a computer program written by Mayo (personal communication), $X-Y$ plots, the equation of the regression line, and correlation coefficients were obtained for all interelement associations. These interrelations are summarized in the form of a correlation matrix (Table 4), and it is clear from this that there are a number of associations. At the $99 \%$ confidence level the following components show a positive correlation with depth: salinity, $\mathrm{Cl}^{-}, \mathrm{SO}_{4}^{--}, \mathrm{Cu}, \mathrm{Ca}, \mathrm{Sr}$, and $\mathrm{Li}$; a negative correlation is shown by alkalinity, $\mathrm{P}_{2} \mathrm{O}_{5}, \mathrm{Mg}$, and $\mathrm{K}$. Not surprisingly, most elements show a positive correlation with salinity, but $\mathrm{Mg}, \mathrm{K}$, and $\mathrm{Ba}$ are notable for their negative correlation. Many components show strong positive correlations with alkalinity, including $\mathrm{P}_{2} \mathrm{O}_{5}, \mathrm{Mg}$, and $\mathrm{K}$, but $\mathrm{Cl}, \mathrm{Ca}, \mathrm{Sr}$, and $\mathrm{Li}$ all show a strong negative correlation. $\mathrm{pH}$ is notable for its paucity of significant correlations; only $\mathrm{Mn}$ and $\mathrm{K}$ show a correlation with $p \mathrm{H}$ at the $99 \%$ confidence level. Some of the more important components will now be considered in some detail.

$$
\begin{gathered}
\text { Anions } \mathrm{Cl}^{-}, \mathrm{SO}_{4}^{--}, \mathrm{HCO}_{3}^{-} \text {(Alkalinity), and } \\
\mathrm{PO}_{4}^{---}\left(\mathrm{P}_{2} \mathrm{O}_{5}\right)
\end{gathered}
$$

These four anions make up the dominant anionic components in ocean waters and pore waters of essentially oceanic origin. However, in pore waters from Site 262 , the relative proportions, as well as the absolute amounts, deviate markedly from those in seawater and most other pore waters in deep-ocean sediments.

Chlorinity and salinity gradually increase down the hole, attaining a maximum of $33.1 \% \mathrm{Cl}$, equivalent to a salinity increase of about $50 \%$ above normal seawater. In previous DSDP drilling, salinities of this order have been encountered only in areas underlain by evaporites, such as the Red Sea (Leg 23). It therefore seems reasonable to postulate that the high Timor Trough salinities possibly result from the influx of brines, emanating from evaporite deposits which may underlie the Timor Trough. There is no direct evidence of such evaporites, although the shallow-water aspects of sediments at the bottom of the hole suggest that such deposits are certainly possible.

The sulfate content of the pore waters also increases down the hole and there is a $99 \%$ probability that $\mathrm{SO}_{4}^{--}$ correlates positively with $\mathrm{Cl}^{-}$, which is the normal relationship. Despite the high salinities, the $\mathrm{SO}_{4^{--}}$ content of the waters is abnormally low (Table 2) compared with seawater and most other pore waters, implying that $\mathrm{SO}_{4}^{--}$is being extracted from the system. This will occur readily at high salinities (greater than about $39^{\prime \prime} / 00$ total dissolved salts) when gypsum precipitates out.

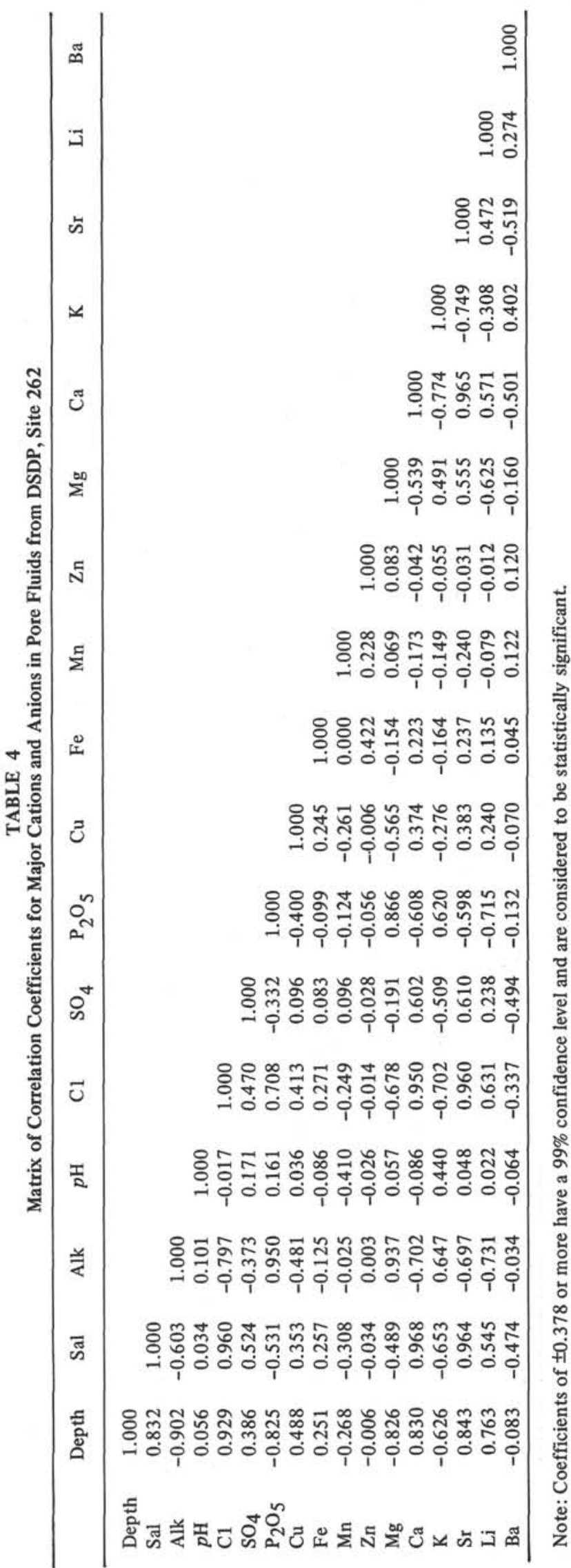

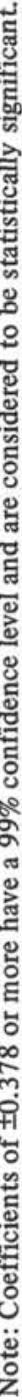




$$
\mathrm{Ca}^{++}+\mathrm{SO}_{4}^{--} \rightleftharpoons \mathrm{CaSO}_{4}
$$

The positive correlation between $\mathrm{Ca}$ and $\mathrm{SO}_{4}$ at a greater than $99 \%$ confidence level supports the validity of this reaction. However, the situation is rather more complex as $\mathrm{SO}_{4}^{--}$is apparently being withdrawn from the system in the upper half of the hole at salinities which would normally be insufficient for precipitation of $\mathrm{CaSO}_{4}$. This suggests that some other mechanism may be involved. Sulfate-reducing bacteria may be present in the sediments producing reactions such as:

$$
\begin{gathered}
\mathrm{SO}_{4}^{--}+2 \mathrm{C} \rightleftharpoons \mathrm{S}^{--}+2 \mathrm{CO}_{2} \\
\mathrm{SO}_{4}^{--}+\mathrm{CH}_{4} \rightleftharpoons \mathrm{HS}^{-}+\mathrm{HCO}_{3}^{-}+\mathrm{H}_{2} \mathrm{O}
\end{gathered}
$$

Both equations only approximate the natural reactions because of the highly complex nature of the organic material (see Berner, 1971, p. 114-137), but are useful as simplistic models of the true systems. The abundance of pyrite in the sediments, the high alkalinity values, and the large quantities of $\mathrm{CO}_{2}$ and $\mathrm{CH}_{4}$ encountered during drilling all lend support to the importance of Equations 2 and 3 .

Alternative equations for the decomposition of carbohydrates and protein in the anaerobic calcareous sediments in the presence of sulfate-reducing bacteria are given by Berner (1966).

$$
\begin{gathered}
2 \mathrm{CH}_{2} \mathrm{O}+\mathrm{SO}_{4}^{--}+\mathrm{CaCO}_{3} \rightleftharpoons \mathrm{Ca}^{++} \\
+\mathrm{HS}^{-}+3 \mathrm{HCO}_{3}^{-} \\
4 \mathrm{CH}_{2} \mathrm{NH}_{2} \mathrm{COOH}+4 \mathrm{H}_{2} \mathrm{O}+3 \mathrm{SO}_{4}^{--}+\mathrm{CaCO}_{3} \\
\rightleftharpoons 3 \mathrm{HS}^{-}+\mathrm{Ca}^{--}+9 \mathrm{HCO}^{-}{ }_{3}+4 \mathrm{NH}_{4}{ }^{+}
\end{gathered}
$$

In the lower half of the hole, below a depth of about 280 meters, salinities may become sufficiently high for the reaction represented by Equation 1 to become of major importance. Above this depth, sulfate reduction is probably the dominant mechanism for the extraction of sulfate.

It is evident from Equations 2-5 that in a closed system an increase in the activity of sulfate-reducing bacteria will lead to a decrease in the amount of $\mathrm{SO}_{4}{ }^{--}$ and a consequent increase in the amount of $\mathrm{HCO}_{3}{ }^{-}$in solution. This should result in a negative correlation between sulfate and alkalinity, and this is indeed the case at the $98 \%$ confidence level (Table 4).

Alkalinity results primarily from the generation of $\mathrm{CO}_{2}$ which then goes into solution. At the $p \mathrm{H}$ levels encountered at Site 262, bicarbonate is the dominant ion (Garrells and Christ, 1965; Krauskopf, 1967) and the reaction may be represented by:

$$
\mathrm{H}_{2} \mathrm{O}+\mathrm{CO}_{2} \rightleftharpoons \mathrm{H}^{-}+\mathrm{HCO}_{3}-
$$

Maximum alkalinity of $93 \mathrm{meq} / \mathrm{l}$ occurs at a depth 50 meters below the sediment-water interface. This is considerably in excess of any alkalinity previously recorded from the Deep Sea Drilling Project. A high rate of sedimentation (about $10 \mathrm{~cm} / 1000 \mathrm{y}$ ) in the Timor Trough is probably instrumental in ensuring that abundant organic material is buried before any extensive oxidation takes place. Alkalinity may reasonably be taken as an indicator of biological activity in general and sulfate reduction in particular (Presley and Kaplan, 1968; Berner et al., 1970). The abundance of organic material and pyrite suggests that conditions are strongly anaerobic within the sediment. Consequently, oxygenation of organic carbon is unlikely to be an important mechanism. Berner (1971) points out that microbiological fermentation reactions can produce $\mathrm{CO}_{2}$ in an anaerobic environment, using the oxygen present in the organic matter. A simplified version of the reaction involving carbohydrate is

$$
\mathrm{C}_{6} \mathrm{H}_{12} \mathrm{O}_{6} \rightleftharpoons 3 \mathrm{CO}_{2}+3 \mathrm{CH}_{4}
$$

It is impossible to evaluate the relative importance of the biologically induced processes of fermentation and sulfate reduction in the determination of alkalinity. However, if alkalinity is an indicator of biological activity it is puzzling that the maximum value occurs at a depth of 50 meters and not just below the sedimentwater interface. The probable explanation for this is that the peak at 50 meters indicative of an ancient peak in biological activity. This would require that the system be closed. Alternatively, present-day biological activity might conceivably extend much farther below the sediment-water interface than is generally acknowledged.

J. Gieskes (personal communication) has suggested that the first alkalinity peak may be a sulfate-reduction peak, whereas the second peak is due to the dominance of fermentation processes.

The relationship between alkalinity and $p \mathrm{H}$ is of some interest, because Gardner (1973) has postulated a theoretical $p \mathrm{H}$-alkalinity relation in calcareous sediments which involves an asymptotic association, with the correlation curve lying parallel to the alkalinity axis at a $p \mathrm{H}$ of about 6.6 (Figure 4). In the Timor Trough system, the asymptote in fact lies at a $p \mathrm{H}$ of 7.4 and 7.8 (Figure 4). This is similar to the Florida Bay results of Berner (1966) who places the limit at 7.3 to 7.7. It is probable that the development of $\mathrm{NH}_{4}{ }^{+}$and other ions which are not generally considered in theoretical systems are responsible for much of the deviation noted between the theoretical and the natural system.

Although $\mathrm{P}_{2} \mathrm{O}_{5}$ (primarily in the form of $\mathrm{PO}_{4}^{---}$) makes a contribution to alkalinity, Gieskes and Rogers (1973) have shown that this contribution is negligible in most natural systems. Despite this, there is a strong positive correlation between alkalinity and $\mathrm{P}_{2} \mathrm{O}_{5}$ (Table 4). $\mathrm{P}_{2} \mathrm{O}_{5}$ also shows a significant positive correlation with $\mathrm{Mg}$ and $\mathrm{K}$. This is perhaps a secondary correlation owing to the $\mathrm{Mg}$ and $\mathrm{K}$ content being dependent on alkalinity rather than from any tendency for these components to be $\mathrm{PO}_{4}^{---}$dependent, although it is not 


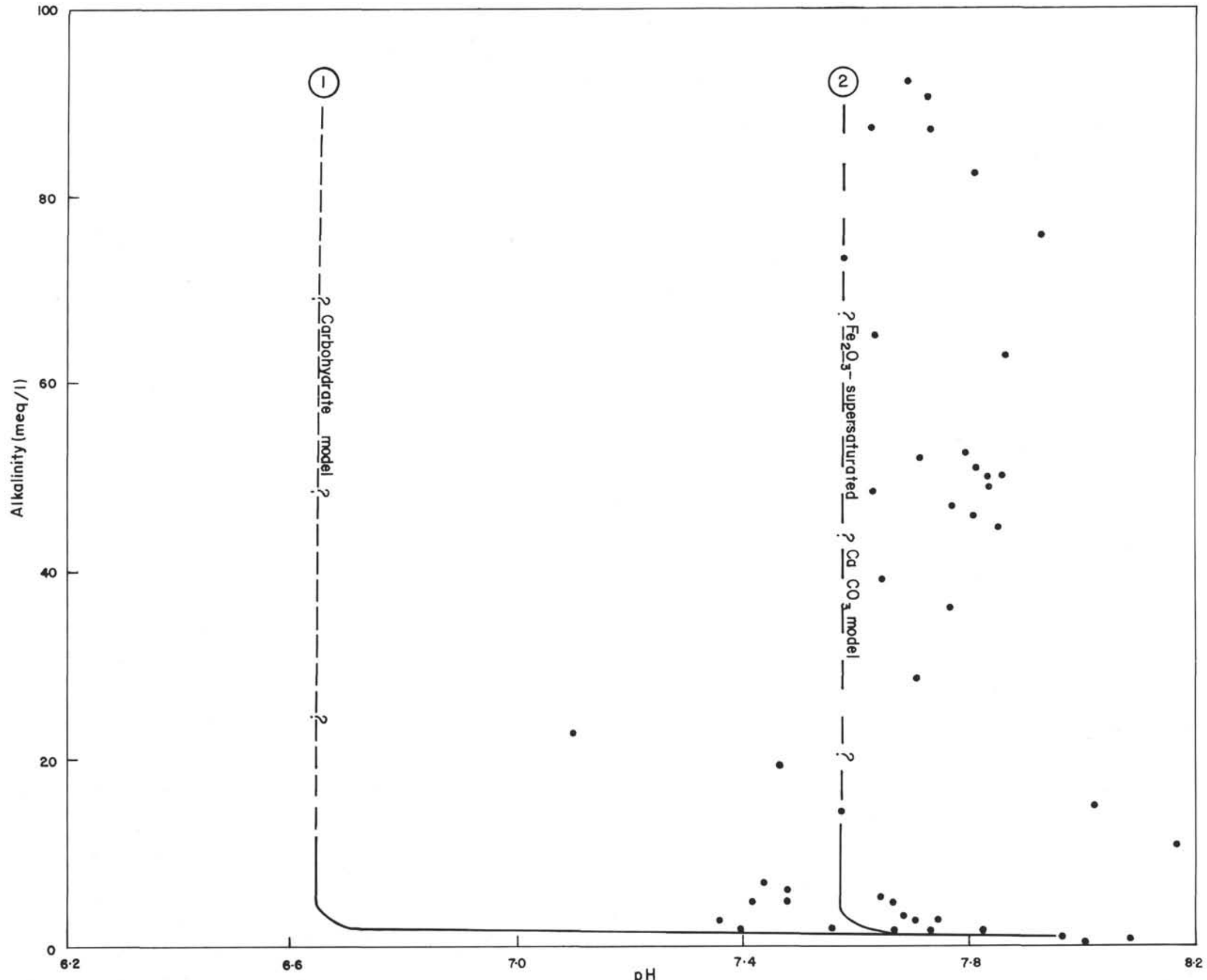

Figure 4. Location of Site 262 samples with respect to the theoretical alkalinity - $p \mathrm{H}$ relations in calcareous sediments, derived by Gardner, 1973. 
clear why $\mathrm{Mg}$ and $\mathrm{K}$ should be alkalinity dependent. A possible explanation for the $\mathrm{P}_{2} \mathrm{O}_{5}$-alkalinity correlation is that the nutrient role of the phosphate radical is of some importance, so that abundant nutrients produce an increase in biological activity which, in turn, results in a high alkalinity value. Alternatively, alkalinity may itself have a direct influence on phosphate solubility.

\section{$\mathrm{Ca}, \mathrm{Mg}, \mathrm{K}, \mathrm{Sr}, \mathrm{Ba}, \mathrm{Li}$}

These alkaline earth metals are commonly associated in aqueous systems, but at Site 262 the interrelations of these ions in pure waters appear to be fairly complex. All these cations will show a straight-line correlation with salinity if precipitation of components does not take place. Thus, $\mathrm{Ca}, \mathrm{Sr}$, and $\mathrm{Li}$ all show a strongly positive correlation with salinity (see Figures $5 \mathrm{a}$ and $5 \mathrm{~b}$ ). $\mathrm{Mg}, \mathrm{K}$, and $\mathrm{Ba}$, on the other hand, all show a negative correlation with salinity (Figure 5c). The complex nature of these relationships is demonstrated by the $\mathrm{Mg}$ salinity plot (Figure 5d). The regression line indicates a negative correlation, but this oversimplifies the true picture as there are two distinct trends. At low salinities, $\mathrm{Mg}$ varies from 800 to $1600 \mathrm{ppm}$ without any sympathetic change in salinity. This near-horizontal trend is confined to the upper half of the section at Site 262. The second trend is a strongly positive correlation between salinity and $\mathrm{Mg}$ content. Samples lying on this positive correlation line are located in the lower half of the hole. The implication of these twodivergent trends is that there are two scurces of pore water: The first is oceanic water which has been incorporated and subsequently modified in situ in the interstices of the calcareous ooze in the upper half of the hole. The second, found in the lower half of the hole, is derived from (or at least modified by) the influx of saline brines possibly emanating from inferred underlying evaporite deposits.
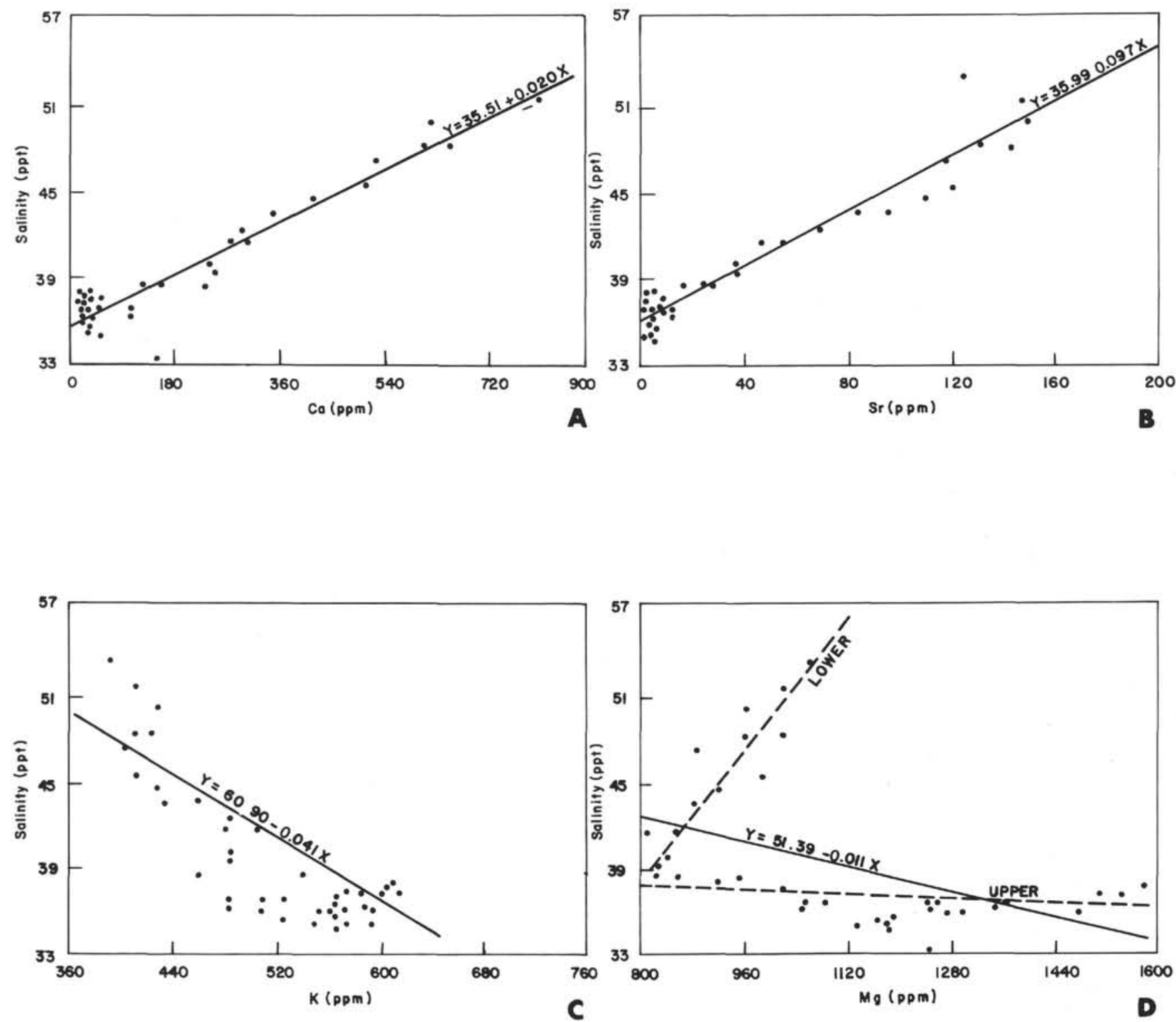

Figure 5. Interrelations of various ions with salinity in Site 262 pore waters. Solid correlation lines have been calculated; dashed lines are approximate. 
This twofold sources of interstitial fluids is also reflected in the $\mathrm{Mg}$-Ca plot (Figure 6), with totally different regression lines in the upper and lower halves of the drill hole. The regression line in the lower half of the hole conforms to the more normal $\mathrm{Mg}$-Ca positive correlation, whereas the negative trend in the upper half of the hole suggests either that $\mathrm{Ca}$ is being removed or $\mathrm{Mg}$ is being added to the system. Figure 7 shows that there is no marked change in salinity in the upper half of the hole associated with the change in the $\mathrm{Mg} / \mathrm{Ca}$ ratio. Table 1 confirms that the high $\mathrm{Mg} / \mathrm{Ca}$ values result primarily from low $\mathrm{Ca}$ concentrations. The correlation matrix (Table 4) indicates that the abundance of $\mathrm{Mg}$ solution may be controlled in part by the alkalinity of the solution. Figure 6a shows the good positive correlation (confidence level greater than $99 \%$ ) that exists between alkalinity and $\mathrm{Mg}$. The Ca-alkalinity plots (Figure $6 \mathrm{~b}$ ) shows a very different form, with the correlation line approximating an asymptotic curve.

The deficiency of $\mathrm{Ca}$ in the interstitial waters of the Timor Trough calcareous sediments is perhaps somewhat surprising. However, Berner (1966) found a similar feature in calcareous Florida sediments. He concluded that excess dissolved $\mathrm{HCO}_{3}-$ was the prime
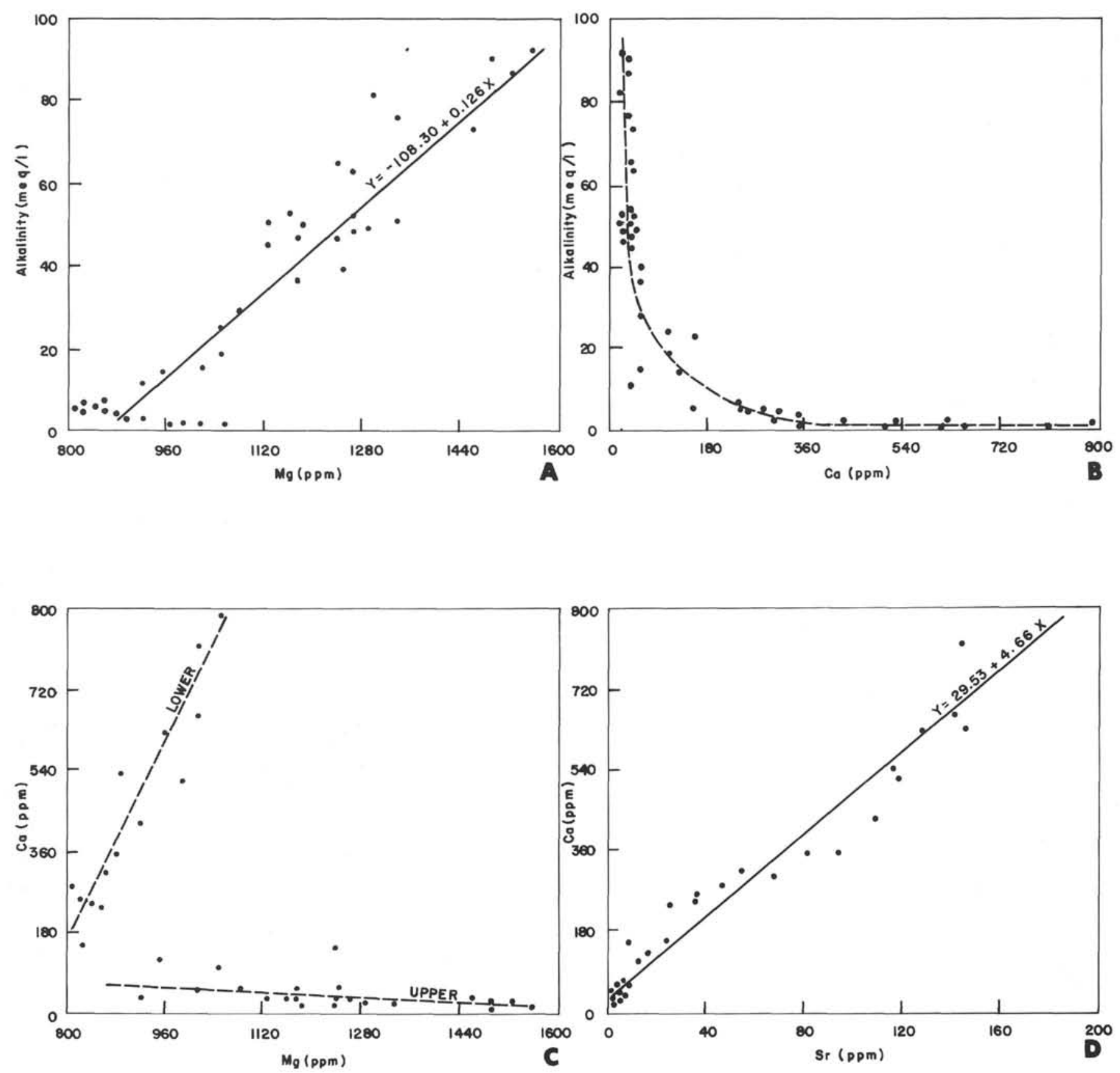

Figure 6. Interrelations of various components in Site 262 pore waters. Solid correlation lines have been calculated; dashed lines are approximate. 
cause of the deficiency, but suggested that $\mathrm{Ca}$ may also be extracted by the precipitation of calcium phosphate. The alternative explanation does not appear to be tenable for the Timor Trough sediments as there is no sympathetic depletion of phosphate in solution. Gardner (1973) offers the further alternative that in the presence of $\mathrm{Fe}_{2} \mathrm{O}_{3}$, sulfate reduction causes the precipitation of $\mathrm{CaCO}_{3}$ and a consequent loss of $\mathrm{Ca}^{++}$ from solution. Although the $\mathrm{Fe}_{2} \mathrm{O}_{3}$ content of the sediments at Site 262 was not determined, comparison of the total $\mathrm{Fe}$ content (Table 1) with the pyrite content as determined by X-ray diffraction (Zemmels and Cook, this volume) suggests that $\mathrm{Fe}_{2} \mathrm{O}_{3}$ is probably abundant.

$\mathrm{Sr}$ and $\mathrm{Ca}$ are closely associated and show a strong positive correlation (Figure 6d). However, there are evidently other factors controlling $\mathrm{Sr}$ solubility in addition to $\mathrm{Ca}$, for the $\mathrm{Ca} / \mathrm{Sr}$ ratio in normal seawater is approximately 56 , whereas at Site $262 \mathrm{Ca} / \mathrm{Sr}$ ranges from 5 to 20 . This indicates that despite the marked absolute decrease in the amount of $\mathrm{Sr}$ in these pore waters compared with the abundance of $\mathrm{Sr}$ in normal oceanic waters, there is an enrichment when compared with $\mathrm{Ca}$ abundance. Figure $7 \mathrm{~b}$ suggests that the $\mathrm{Ca} / \mathrm{Sr}$ ratio may be partly controlled by $\mathrm{Mg}$; as the concentration of $\mathrm{Mg}$ increase so the relative abundance of $\mathrm{Sr}$ decreases compared to $\mathrm{Ca}$. The reason for this apparent association is not known.

\section{$\mathrm{Cu}, \mathrm{Fe}, \mathrm{Mn}, \mathrm{Zn}$}

All the transition group elements tend to behave in a similar fashion in that they show a marked increase in concentration in the pore waters compared to the concentrations encountered in surface seawater (Table 2). However, there are few clear correlations between these transition elements or with most of the other porewater components. This is evident from the low correlation coefficients in Table 4.

$\mathrm{Fe}$ and $\mathrm{Zn}$ vary sympathetically but show no other significant correlations. Copper, on the other hand, does show significant positive correlations with depth, salinity, and chlorinity, and negative correlations with alkalinity, $\mathrm{P}_{2} \mathrm{O}_{5}$, and $\mathrm{Mg}$. $\mathrm{Mn}$ correlates negatively with $p \mathrm{H}$. Overall, however, $\mathrm{Cu}, \mathrm{Fe}, \mathrm{Mn}$, and $\mathrm{Zn}$ show few definite patterns in these pore waters, and no definite conclusions can be reached regarding the mechanism controlling their concentration.

\section{Sediments}

\section{Mineralogy}

X-ray diffraction analyses by the writer and by Cook, Zemmels, and Matti (this volume) indicate that the sediments at Site 262 are composed predominantly of calcite and clay minerals, with various amounts of aragonite, dolomite, quartz, and feldspar, and traces of pyrite and zeolites. There is a marked increase in the proportion of calcareous components with depth. There are also marked mineralogical changes in the calcareous fraction, with the proportion of dolomite increasing with depth. The proportion of aragonite in the carbonate fraction remains fairly constant throughout.
Using the method of Goldsmith and Graf (1958), it is possible to determine the amount of $\mathrm{Mg}$ substituting in the calcite lattice. There is a slight increase in the amount of substitution of $\mathrm{Mg}$ in the lattice with increasing depth, but throughout the calcite is of the low-magnesian variety ranging from Ca1.00 $\mathrm{Mg}_{0.00} \mathrm{CO}_{3}$ to $\mathrm{Ca}_{0.97} \mathrm{Mg}_{0.03} \mathrm{CO}_{3}$. The dolomite-type remains fairly constant and is an $\mathrm{Mg}$-deficient form, ranging from $\mathrm{Ca} 0.60 \mathrm{Mg}_{0.40} \mathrm{CO}_{3}$ to $\mathrm{Ca}_{0.54} \mathrm{Mg}_{0.46} \mathrm{CO}_{3}$. There does not appear to be any regular variation in the dolomite composition. The complete lack of any high- $\mathrm{Mg}$ calcite, even in the upper part of the hole where there is negligible dolomite, is somewhat surprising since the calcite is of biogenic origin. It is possible that the metastable high-magnesian calcite has reverted to lowmagnesian calcite and dolomite. If this has in fact taken place, then the lack of a significant decrease in the abundance of metastable aragonite is rather puzzling.

\section{Chemistry}

The major and trace-element composition of the Site 262 calcareous oozes is summarized in Table 1. It is apparent from this that there are some marked differences in the elemental composition of sediments in the upper half of the hole and those in the lower half. For example, the Ca composition of the total sediment in the upper half of the hole averages $12.6 \%$ compared with $25.0 \%$ in the lower half. On the other hand, the $\mathrm{Mg}$ content of the total sediment only shows a small variation $(1.23 \%$ to $1.54 \%)$ despite an increase in the dolomite component of the calcareous fraction from $2.0 \%$ to $14.5 \%$. The vertical variations in both elemental and mineralogical compositions are summarized in Figure 3.

Despite these vertical changes, the average inorganic composition of the Site 262 oozes is very similar to the average composition of Leg 27 Cenozoic calcareous oozes (Table 3 ), and there is, in turn, nothing to indicate that these differ from normal oceanic calcareous oozes. Consequently, none of the unusual features of the porewater composition can be explained on the basis of inorganic sediment composition. The fundamental abnormal feature is believed to be the abundance of organic plant material (producing organic carbon values of $1 \%$ and more) which has been incorporated in the sediment as a result of the close proximity of the Timor Trough to land and the extremely rapid rate of sedimentation. The organic carbon is available as a biological nutrient. This ultimately results in the high alkalinities encountered in the sediments and is also responsible for the abundant pyrite; it may also play a role in the modification of carbonate mineralogy.

\section{Noncalcareous Components}

Elements thought to fall into this category include $\mathrm{Al}$, $\mathrm{Fe}, \mathrm{Co}, \mathrm{Ni}, \mathrm{Cr}, \mathrm{Pb}, \mathrm{Cu}, \mathrm{Mn}, \mathrm{Zn}, \mathrm{Li}$, and $\mathrm{Ba}$. All appear to be interrelated and commonly show positive correlations with each other (and negative correlations with the calcareous components-see Table 5). Some elements (such as $\mathrm{Al}$ and $\mathrm{Fe}$ ) are essential lattice components of the clay minerals, whereas others such as 

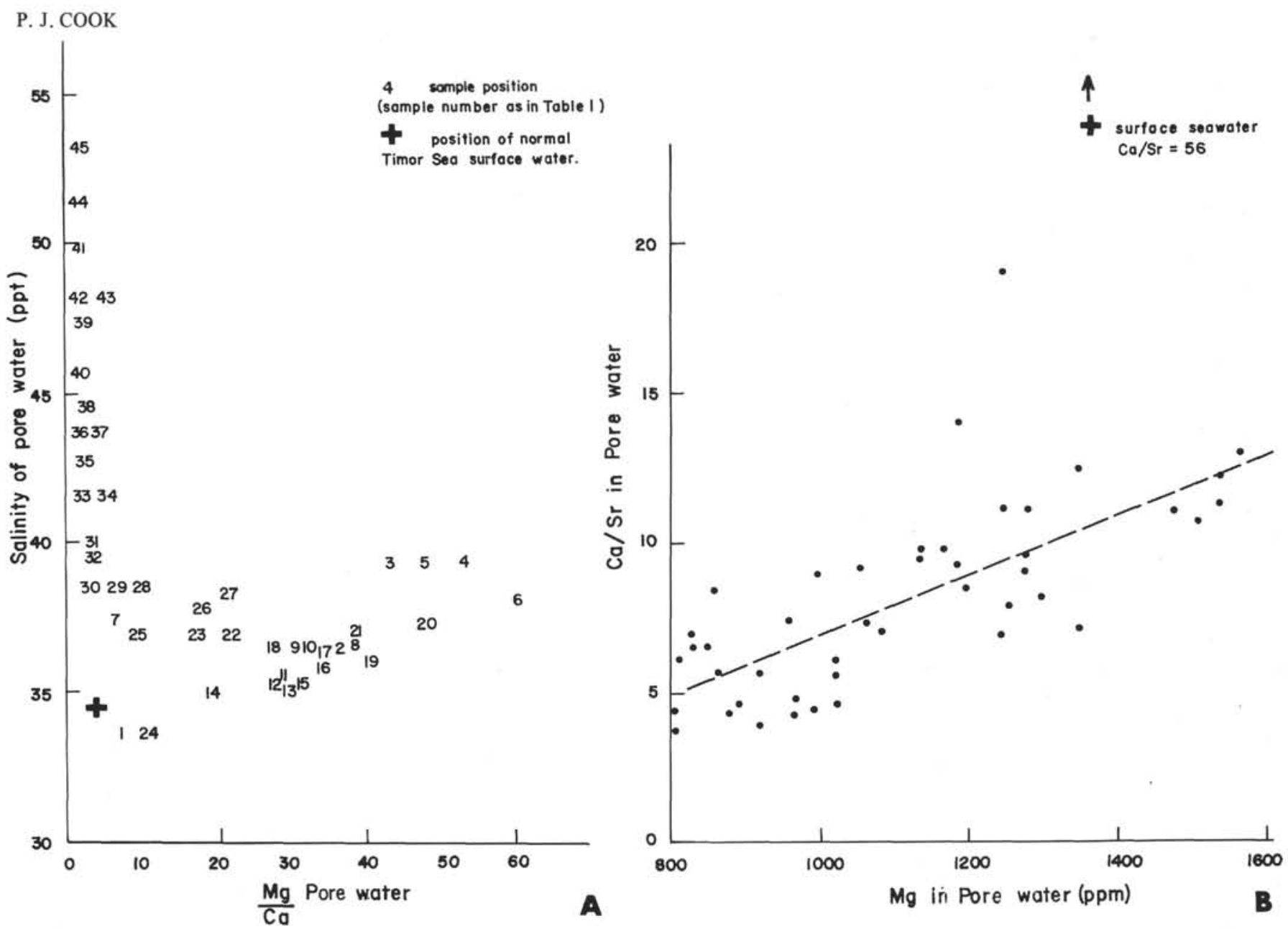

Figure 7. Variation of the $\mathrm{Mg} / \mathrm{Ca}$ ratio in pore waters with salinity and with position at Site 262. Variation of the Ca/Sr ratio with $\mathrm{Mg}$ in Site 262 pore waters.

$\mathrm{Cu}$ and $\mathrm{Zn}$ may be adsorbed on the clay particle surface. Some elements such as Mn may be present as finely divided metallic oxides or complex oxides or hydroxides. There is a marked difference in the $\mathrm{Co}, \mathrm{Ni}, \mathrm{Mn}$, and $\mathrm{Cr}$ content of the calcareous oozes at Site 262 and those of the other Leg 27 Sites. Mn averages 544 ppm, whereas in the other Cenozoic oozes of Leg 27 it averages $2600 \mathrm{ppm}$. The low values at Site 262 may be a reflection of the comparatively shallow water depth, i.e., abyssal zone waters may be richer in Mn. Alternatively, it may be a product of the high rate of sedimentation in the Timor Trough which results in the dilution of any chemical sediments.

Revelle (1944) first suggested that $\mathrm{Ba}$ is associated with carbonate in deep-sea sediments. Goldberg and Arrhenius (1958) subsequently suggested that the Ba content of deep-sea sediments is a function of the organic production of the euphotic zone, which is in turn partly dependent on latitude. Brongersma-Sanders (1967) showed that $\mathrm{Ba}$ becomes concentrated to a considerable degree in some diatom skeletons. In the Timor Trough sediments at Site 262, Ba correlates positively (at the $99 \%$ confidence level) with $\mathrm{Al}_{2} \mathrm{O}_{3}, \mathrm{Fe}$, and all the other noncalcareous components (see Table 5 ) and shows a negative correlation with the calcareous components. There is, therefore, no evidence from these analyses that $\mathrm{Ba}$ content is related to $\mathrm{CaCO}_{33}$. It could conceivably be related to the abundance of siliceous organisms, but its strongest associations appear to be with terrigenous components such as clay minerals (as indicated by the $\mathrm{Ba}-\mathrm{Al}_{2} \mathrm{O}_{3}$ association) or with (?) inorganically precipitated oxides such as $\mathrm{MnO}$ (as indicated by the Ba-Mn association).

\section{Calcareous Components}

Elements thought to fall into this category include $\mathrm{Ca}$, $\mathrm{Mg}, \mathrm{C}$ (expressed as $\left.\mathrm{CO}_{2}\right), \mathrm{Sr}$, and $\mathrm{P}\left(\right.$ as $\left.\mathrm{P}_{2} \mathrm{O}_{5}\right)$. All show good positive correlations with each other and negative correlations with the noncalcareous group of elements $\left(\mathrm{Al}_{2} \mathrm{O}_{3}\right.$, etc. - see Table 5). Calcareous components show a marked increase in abundance with increasing depth. The positive correlation between $\mathrm{P}_{2} \mathrm{O}_{5}$ and $\mathrm{Ca}$ suggests that much of the $\mathrm{P}_{2} \mathrm{O}_{5}$ may be of biogenic origin and is incorporated in the skeletons of microfossils.

$\mathrm{Sr}$ values are fairly normal, in general. except Core 2 (Table 1) which appears to be anomalously high. A strongly positive correlation is evident between $\mathrm{Sr}$ and $\mathrm{Ca}$, but there is a weakly negative trend between $\mathrm{Sr}$ and $\mathrm{Mg}$. This may be a reflection of the loss of $\mathrm{Sr}$ as a result of the dolomitization of calcite, i.e., replacement of $\mathrm{Ca}$ by $\mathrm{Mg}$. There are marked variations in the $\mathrm{Ca} / \mathrm{Mg}$ ratio which might reasonably be expected to correlate with 


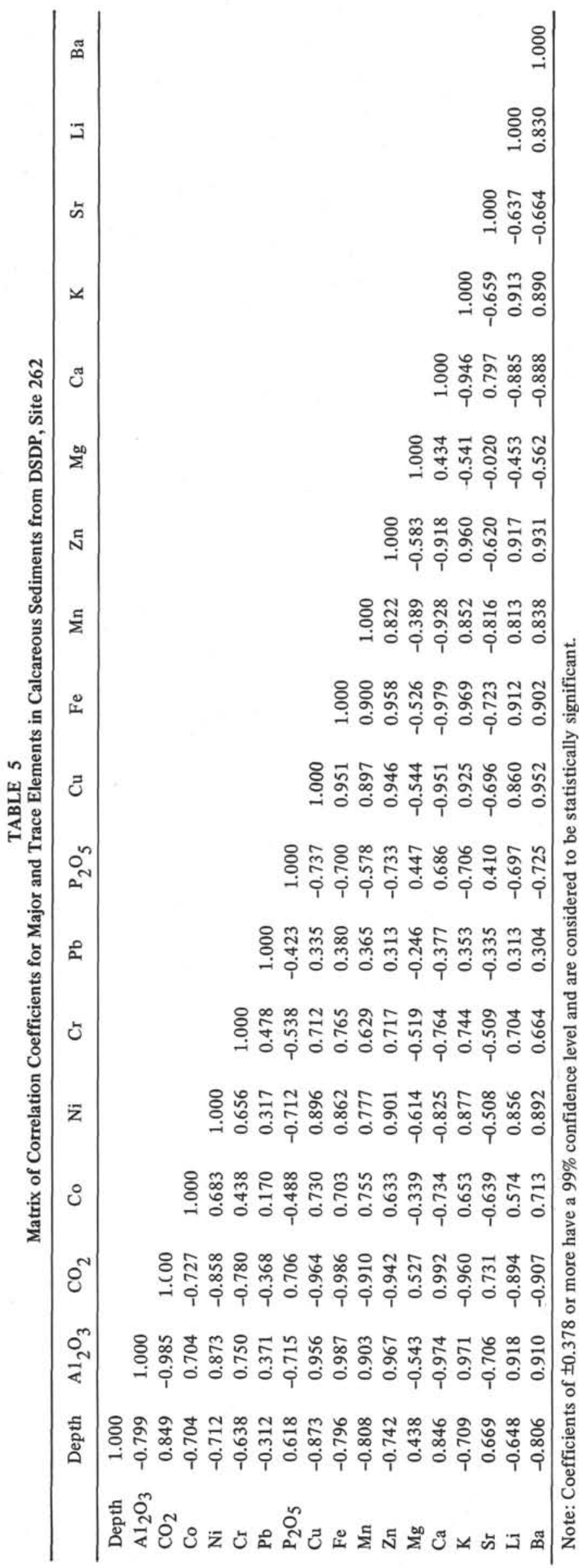

the abundance of dolomite if the dolomite has, in fact been formed by the dolomitization of calcite, but such a trend is not clearly defined (Figure 8 ). This may be partly because a significant amount of the $\mathrm{Mg}$ present in the sediments is associated not with dolomite (or magnesian calcite) but with the clay minerals. Additional possible mechanisms include direct precipitation of dolomite from solution rather than forming by the diagenetic dolomitization of calcite. Alternatively, some of the dolomite may be allochthonous, derived from an older formation which is presently being eroded, but the Mg-deficient nature of the dolomite suggests that the dolomite is comparatively young.

If the trends of calcareous components in the sediments are compared with the trends of these same elements in the pore waters, correlations are, in general, either completely lacking, or, at best, poorly defined. This is probably the result of most of the cations and anions in solution being derived from the original seawater rather than from the adjacent sediments.

However, there is a well-defined positive correlation between the concentration of $\mathrm{Mg}$ in the pore water and the abundance of dolomite in the sediments. The $\mathrm{Mg} / \mathrm{Ca}$ ratio does not appear to have any great importance in the dolomitization process in this particular environment. This is unlike the supratidal environment where the $\mathrm{Mg} / \mathrm{Ca}$ ratio is of some importance (Muller et al., 1972; Cook, 1973).

$\mathrm{Ca}$ concentration in the interstitial waters shows a poorly defined positive trend with $\mathrm{Ca}$ concentration in the sediments, but alkalinity appears to have a much greater influence. $\mathrm{Sr}$ and $\mathrm{P}_{2} \mathrm{O}_{5}$ in solution show no obvious correlation with the $\mathrm{Sr}$ and $\mathrm{P}_{2} \mathrm{O}_{5}$ content of the sediments. The transition metals in pore waters and sediment also fail to show any sympathetic trends.

\section{SUMMARY AND CONCLUSIONS}

The sediments of Site 262 are similar in composition to most other deep-sea calcareous oozes. The only exception to this is that $\mathrm{Mn}, \mathrm{Ni}, \mathrm{Co}$, and $\mathrm{Cr}$ are somewhat impoverished. This may result from the comparative shallowness of the oozes at Site 262 or, alternatively, is a consequence of the rapid rate of terrigenous and biogenic sedimentation which dilutes chemical sedimentation. The dominant trend in the sediments is one of increasing abundance of carbonate with increasing depth. This has a marked effect on the major- and trace-element geochemistry of the sediments, yet has little influence on the geochemistry of the pore fluids. By contrast, the organic-matter content of the sediments is believed to have a very marked effect on the chemistry of the pore waters. The organic matter present in the sediments is used by bacteria in sulfate reduction and fermentation reactions and the net effect of this is to produce abnormally high alkalinities in the pore waters. A sympathetic association between alkalinity and the $\mathrm{Mg}, \mathrm{K}$, and $\mathrm{P}_{2} \mathrm{O}_{5}$ content of the pore waters is apparent, but the reason for these interrelations is not understood. Other associated effects include the loss of $\mathrm{SO}_{4}{ }^{--}$from solution (by sulfate reduction) and also a decrease in $\mathrm{Ca}^{++}$which may be related to the presence of $\mathrm{Fe}_{2} \mathrm{O}_{3}$ in the sediments (Gardner, 1973). The bacterial processes also result in the formation of pyrite in the sediments. 


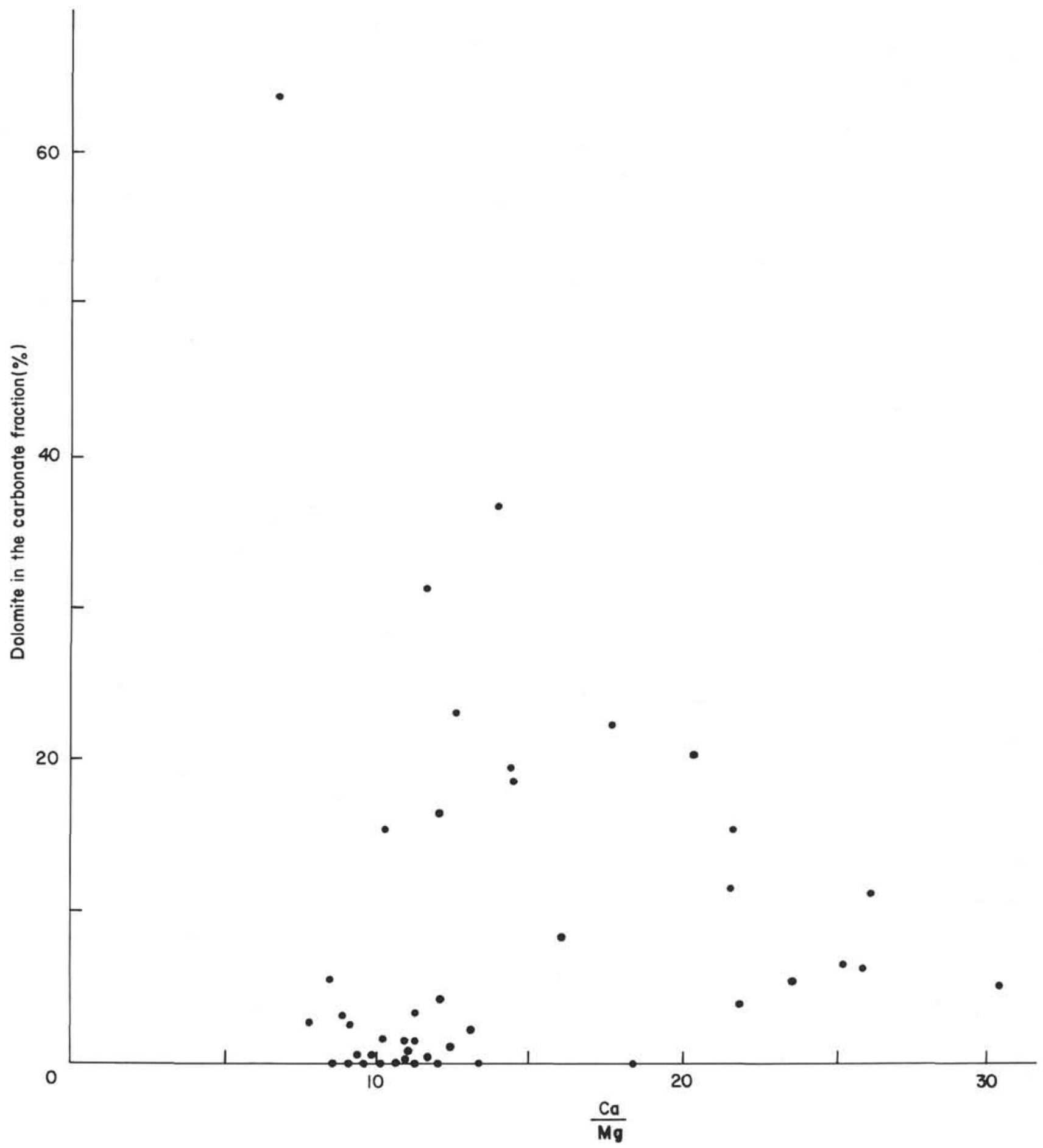

Figure 8. Plot showing lack of any clear correlations between the Ca/Mg ratio and the abundance of dolomite in the sediments. 
A further geochemical trend of some importance is that of increasing salinity with increasing depth. This has a marked effect on both the anionic and cationic composition of the pore waters. It is also believed to have some effect on the sediment composition and particularly the abundance of dolomite, as dolomite also shows a marked increase in abundance with increasing depth. There is also a poorly defined trend of increasing substitution of $\mathrm{Mg}$ in the calcite lattice with increasing depth, but the complete absence of high-magnesian calcite is a puzzling feature, particularly as metastable aragonite is present throughout the hole.

In conclusion, there are three basic geochemical trends with increasing depth at Site 262. These may be generalized as (1) decreasing alkalinity, which is primarily a reflection of decreasing bacterial activity with depth; (2) increasing salinity; and (3) increasing abundance of carbonates in the sediment.

A summary of the three trends is shown in Figure 9. Elements which are dependent primarily on one of these factors such as $\mathrm{P}_{2} \mathrm{O}_{5}$ and alkalinity (or bacterial activity) has a trend parallel to that factor. An element which is dependent on more than one factor, such as $\mathrm{Mg}$, has a considerably more complex distribution pattern. Bacterial activity is thought to have a particularly marked effect on the pore-water composition in the upper half of the hole, whereas the effects of hypersalinity are dominant in the lower half. Both these features have a significant effect on the diagenetic changes taking place in the sediments.

\section{ACKNOWLEDGMENTS}

The writer acknowledges the valuable contributions made to this portion of the Leg 27 program by J. Pine of the Deep Sea Drilling Project who carried out the onboard extractions and determinations, and the staff of the Analytical Chemistry Section of the Australian Mineral Development Laboratories who were responsible for most of the onshore geochemical analyses. The assistance of W. Mayo, G. Berryman, and K. J. Armstrong of the Bureau of Mineral Resources is also greatly appreciated.

\section{REFERENCES}

Berner, R. A., 1966. Chemical diagenesis of some modern carbonate sediments: Am. J. Sci., v. 264, p. 1.

197I. Principles of chemical sedimentology: New York (McGraw-Hill).

Berner, R. A., Scott, M. A., and Thomlinson, C., 1970. Carbonate alkalinity in the porewaters of anoxic marine sediments: Limnol Oceanogr., v. 15, p. 544.

Brongersma-Sanders, M., 1967. Barium in pelagic sediments and in diatoms: Koinkl. Nederland Akad. Wetensch. Proc., v. 70 p. 93.

Cook, P. J., 1973. The supratidal environment and geochemistry of some recent dolomite concretions, Broad Sound, Queensland: J. Sediment. Petrol., v. 43, p. 998.

Gardner, L. R., 1973. Chemical models for sulfate reduction in closed anaerobic marine environments: Geochim. Cosmochim. Acta, v. 37, p. 53.

Garrells, R. M. and Christ, C. L., 1965. Solutions, Minerals, Equilibria: New York (Harper).

Gieskes, J. M. and Rogers, W. C., 1973. Alkalinity determinations in interstitial waters of marine sediments. J. Sediment Petrol., v. 43, p. 272.

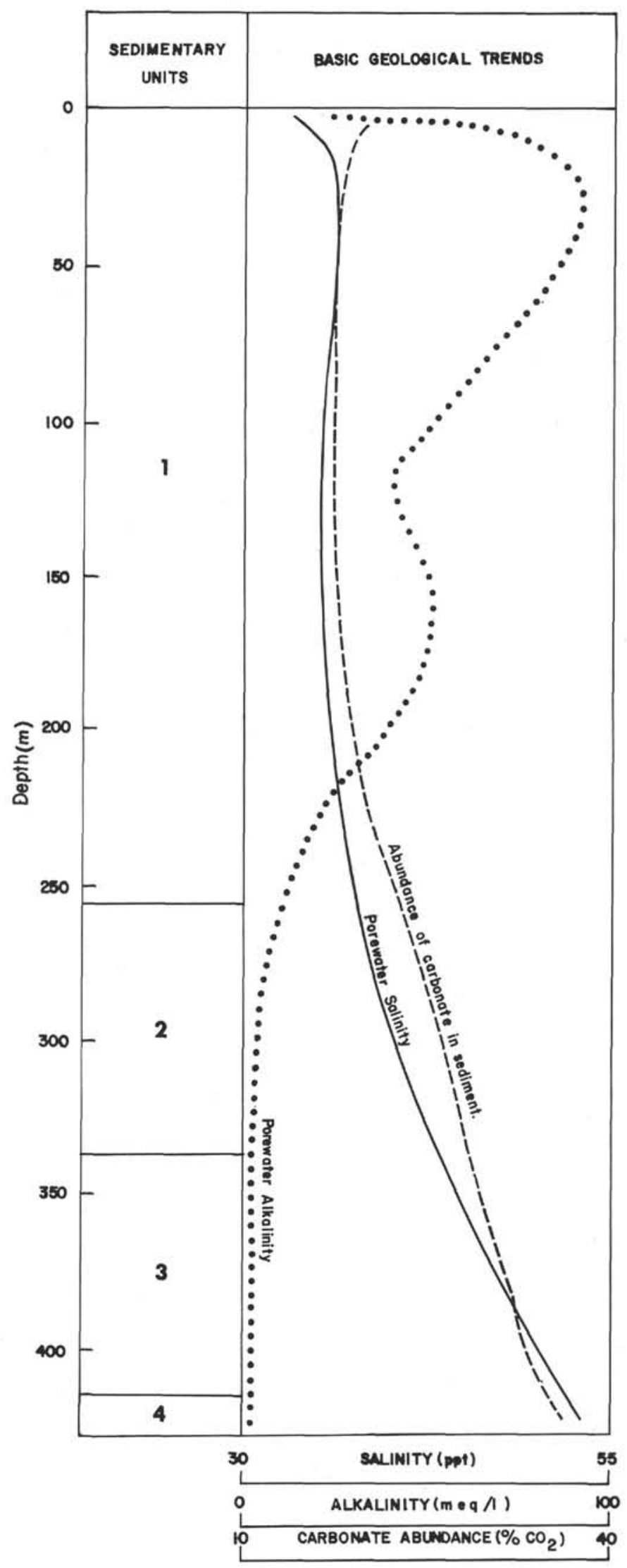

Figure 9. Summary of the three basic geochemical trends at Site 262. 
Goldberg, E. D. and Arrhenius, G., 1958. Chemistry of Pacific pelagic sediments: Geochim. Cosmochim. Acta, v. 13, p. 153.

Goldsmith, J. R. and Graf, D. L., 1958. Relation between lattice constants and composition of the $\mathrm{Ca}-\mathrm{Mg}$ carbonates: Am. Mineral., v. 43, p. 84.

Krauskopf, K., 1967. Introduction to Geochemistry: New York (McGraw-Hill).

Manheim, F. T. and Sayles, F. L., 1971. Interstitial water studies on small core samples, Deep Sea Drilling Project, Leg 8. In Tracey, J. I., Jr. et al., Initial Reports of the Deep Sea Drilling Project, Volume 8: Washington (U.S. Government Printing Office), p. 857.

Muller, G., Irion, G., and Forstner, U., 1972. Formation and diagenesis of inorganic $\mathrm{Ca}-\mathrm{Mg}$ carbonates in the lacustrine environment: Naturwiss., v. 59, p. 158.

Murphy, J. and Riley, J. P., 1962. A modified single solution method for the determination of phosphate in natural waters: Anal. Chim. Acta, v. 27, p. 31.
Presley, B. J. and Kaplan, I. R., 1968. Changes in dissolved sulfate, calcium and carbonate from interstitial waters of nearshore sediments: Geochim. Cosmochim. Acta, v. 32, p. 1037.

1971. Interstitial waters chemistry, Deep Sea Drilling Project, Leg. 8. In Tracey, J. I., Jr. et al., Initial Reports of the Deep Sea Drilling Project, Volume 8: Washington (U.S. Government Printing Office), p. 853.

Revelle, R. R., 1944. Marine bottom samples collected in the Pacific Ocean by the Carnegie on its seventh cruise: Publ. Carn. Inst. Washington, v. 556.

St. John, B. E., 1970. Ultra-trace element analysis of carbonate rocks by APDC-MIBK extraction and atomic absorbtion spectrophotometry: J. Sediment. Petrol., v. 40, p. 537.

Thorstenson, D. C., 1970. Equilibrium distribution of small organic molecules in natural water: Geochim. Cosmochim. Acta, v. 34 , p. 745 . 